\title{
Sauropus androgynus (L.) Merr.: a multipurpose plant with multiple uses in traditional ethnic culinary and ethnomedicinal preparations
}

\author{
Thattantavide Anju, Nishmitha Kumari S. R. Rai and Ajay Kumar ${ }^{*}$ (1)
}

\begin{abstract}
Various plants form the basis of multiple traditional ethnic cuisines and ethnomedicinal practices across the globe. The ethnic cuisines cater to the nutritional, dietary and medicinal requirements of the tribal and rural communities even today. Using literature from various scholarly databases, this study was conducted to consolidate a comprehensive review on the use of Sauropus androgynus (L.) Merr. in various traditional ethnic cuisines and ethnomedicinal preparations across the globe. The survey shows that it is used in multiple ethnic cuisines and is variously known in different countries and among the communities. Further, it possesses multiple nutritional and ethnomedicinal properties. Considering its importance in ethnic foods and ethnomedicinal preparations, it is important to investigate the nutritional composition, phytochemical constitution and pharmacological basis of ethnomedicinal uses. Therefore, we further compiled this information and found that it is a rich source of both micro- and macronutrients and packed with several bioactive compounds. Survey of pharmacological studies on its traditional medicinal uses supports its ethnomedicinal properties. Despite its importance in traditional food and ethnomedicinal systems, it remains underexplored. Limited information on the toxicity of its various extracts shows that further studies should be conducted to understand its safety aspects. Further clinical studies to prospect possible drug candidates from it should be attempted.
\end{abstract}

Keywords: Sauropus androgynus, Malay cheera, Chakurmani, Chinese soppu, Ethnopharmacology, Ethnic foods, Traditional foods

\section{Introduction}

People across the globe have had intimate relations with plants for food, fodder, medicines and cloths since time immemorial. Although global food systems are highly homogenised and rely on some of the major staple crops such as rice, wheat and maize, many people in different countries still use plant-based traditional ethnic foods [1, 2]. Different ethnic foods may be prepared from a single

\footnotetext{
*Correspondence: botanistajay@gmail.com
}

Department of Plant Science, School of Biological Sciences, Central

University of Kerala, Periye, Kasaragod, Kerala 671316, India plant showing the diversity of ethnic food preparations and their biocultural significance [3]. The ethnic delicacies obtained from the plants may not be very popular globally, but they hold very high local and regional importance in a region or among a community or a society. The traditional recipes vary from one region to the other and formal documentation of preparation of ethnic cuisines may not be available. The knowledge of the ethnic preparations is orally transmitted and sustained through practice [4]. It is only recently that a large number of urban folks have also shown interest in ethnic cuisines. The plants used for the preparations of the ethnic cuisines are original author(s) and the source, provide a link to the Creative Commons licence, and indicate if changes were made. The images or other third party material in this article are included in the article's Creative Commons licence, unless indicated otherwise in a credit line to the material. If material is not included in the article's Creative Commons licence and your intended use is not permitted by statutory regulation or exceeds the permitted use, you will need to obtain permission directly from the copyright holder. To view a copy of this licence, visit http://creativecommons.org/licenses/by/4.0/. 
also often used in the ethnomedicinal preparations that form the basis of limited healthcare in the rural and tribal areas [5]. Therefore it is not surprising that some of the plants used in the ethnic dishes also possess medicinal properties. Sauropus androgynus (L.) Merr. belonging to the family Phyllanthaceae is such a plant with multiple uses in traditional cuisines and ethnomedicinal preparations [6]. S. androgynus is a shrub that grows in high temperature and humid conditions. Its branches are either cylindrical or angled. The leaves are pinnately compound with ovule or lance shape. The flowers are dark red in colour and fruits are globular in shape which is a light yellow colour (Fig. 1) [6]. The S. androgynus is distributed throughout the Southeast Asian mainland and Australia [7]. It is cultivated in India, Bangladesh, and Guangxi, Guangdong, Hainan, and Yunnan provinces of China [8]. Thailand-Indochina and Australia are the two important centres of diversity of Sauropus [7]. The findings of various studies show that $S$. androgynus is used in a number of ethnic recipes in South and Southeast Asia. Various preparation methods are used and the dishes are also known by different names.

The recent COVID-19 pandemic has exposed the fragility of long-distance interconnected mainstream food systems [9]. Disruptions in the transport sector caused due to the pandemic have resulted in food insecurity issues in several countries that heavily rely on food imports [10]. The long-term issues may further arise if the COVID-19 continues and new highly contagious variants emerge [11]. Several recent studies have pointed towards the relevance of the local traditional food systems that are locally adapted. The studies have also demonstrated that those countries or regions that have strong local/traditional food systems have shown increased resilience to the food security challenges during the current pandemic [12]. The COVID-19 has led to an increase in homestead and kitchen gardening in various countries [13, 14]. Therefore although local ethnic food systems may not be contributing to very high food security, they are very relevant under the current circumstances. The local ethnic food systems based on plants can help in strengthening the food security in those areas that are severely affected by COVID-19 in the short term [14]. The ethnic food systems are therefore important and relevant in the present context for increasing the food system resilience as well. The ethnic food systems across the globe should be studied and documented.

The phytochemical and nutritional profiling of the plants used in the traditional food and medicinal systems is crucial to understand the nutritional composition and basis of its ethnomedicinal value. The studies on the nutrient composition of plants used in ethnic cuisines provide an understanding of their relevance in the food security of the tribal and rural communities $[15,16]$. The

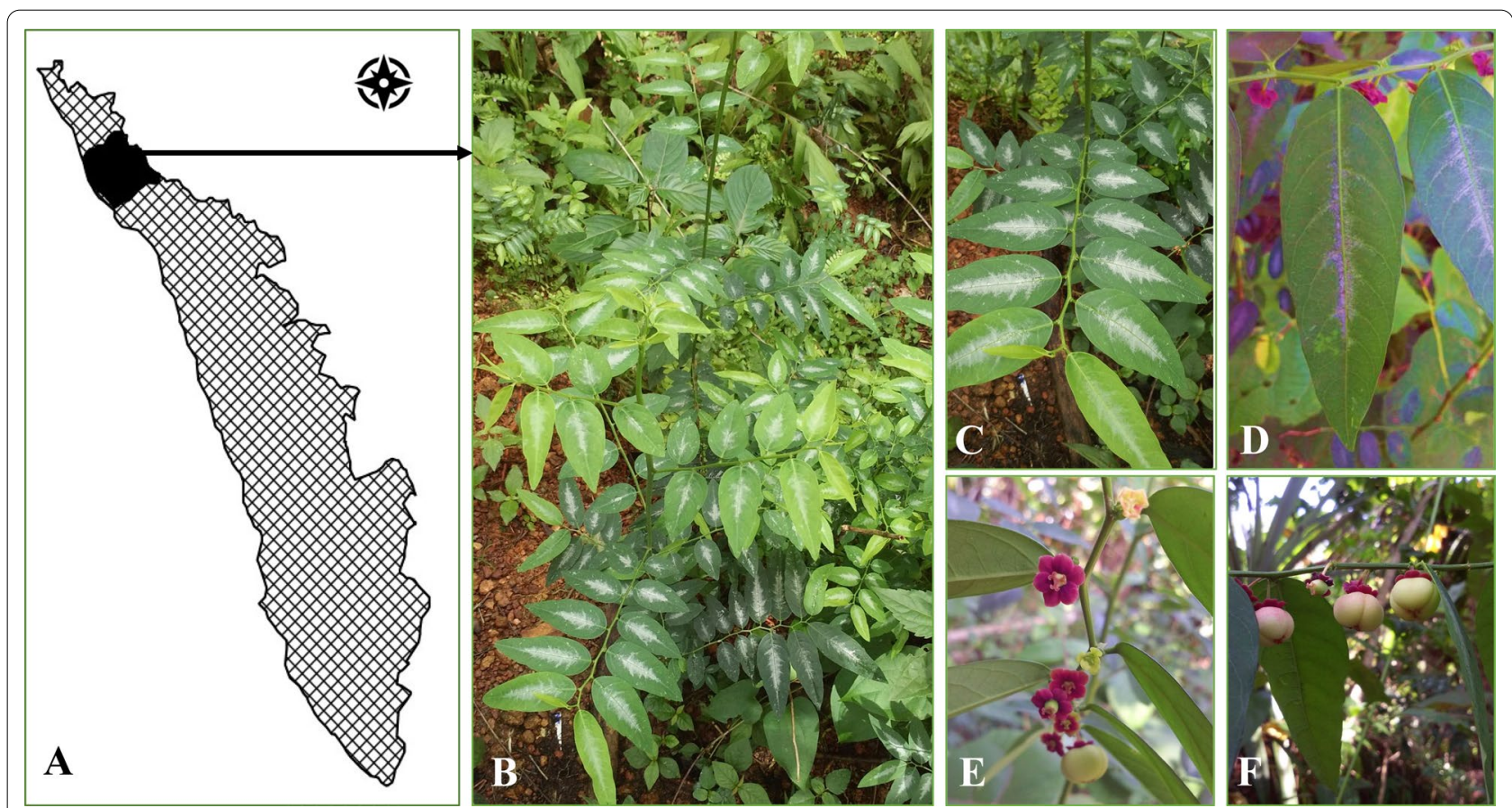

Fig. 1 A. Map showing Kannur district of Kerala state of India where the photos of S. androgynus are captured. The plant and its various parts (B, C). B. Complete plant in its natural habitat, C. a compound leaf, D. a leaflet, E. Flower, and F. Fruits 
medicinal potential of a plant depends on the chemical compounds that are packed inside the plant body with reference to their quantity and quality [17]. The consumption of the plants that possess medicinal as well as nutritional properties is important considering the current health issues and the out of the pocket expenditure of the households not only in the developing countries but also in the developed world $[18,19]$. Medicinal plants are an important part of the healthcare system of the consumers [18]. S. androgynus possess medicinal properties due to its unique phytochemical composition [20]. Various metabolites have been identified and quantified from S. androgynus that suggest its medicinal value [21]. Ethnobotanical studies have revealed that it is traditionally used in various formulations against a wide range of ailments including diabetes, weight loss, diarrhea, cough and ulcer [22-26]. This review particularly focuses on the usage of $S$. androgynus as traditional ethnic food and an ethnomedicinal plant in different parts of the world. Since it is an important part of ethnic cuisines, this article further explores its nutritional composition. To understand the basis of its ethnomedicinal properties, a review on its pharmacological investigation is also performed. The aim of this review is to provide a comprehensive update on the use of various species of S. androgynus for ethnomedicinal and ethnic foods in various tribal and rural communities.

\section{Traditional ethnic preparations from Sauropus androgynus}

S. androgynus is widely consumed and often cultivated in south Asian countries and is adapted to high humidity and high-temperature conditions $[6,7]$. It is a staple vegetable crop and originated in Borneo [27]. The taste of raw leaves is similar to peanuts and cooked leaves taste like spinach [28]. The plants are perennial shrubs with erect stems and dark green leaves. The leaves are compound leaves with a papery texture (Fig. 1) [29]. Seeds are black coloured and the plants develop fruits during July-December. It is majorly propagated through stem cuttings because of the low germination capacity of the seeds [30]. In Indonesia, more than 30 tribal communities cultivate the katuk plant especially in their home gardens and along with cabbage (Brassica oleracea) and beluntas (Pluchea indica) [31]. The vernacular names of the species include katuk, sweet leaf bush, chekusmaria, asin-asin star gooseberry [6, 32]. The plant has various ethnic names in different corners of the world. The Chinese people name the plant as Shu zai cai/ Mani cai/ yue nan cai/ Shou gong mu. In Indonesia, they are known as babing/ Daun katuk/ simani. Among the Japanese people, they are popular as Ruridama-no-ki and among Cambodians as Dom nghob. Hvaan baanz and Binahian are the vernacular names of the plant in Laos and the Philippines respectively. In the case of Malaysia, they have multiple ethnic names such as sayur manis, katuk, cekur manis, asin-asin, cekok manis, changkok manis and cangkok manis. The general name of the plant in Thailand is Phak waan baan but on the northern side, they are known as Kaan tong. Figure 2 represents the world map with ethnic names of S. androgynus in various countries of the world.

In the case of India, the plant has distinct names in distinct states including Sengtungrung (Sikkim), malay cheera (Kerala), Chakrmani (Andaman and Nicobar islands), Chakurmani (West Bengal), Chinese soppu (Karnataka) and Dieng soh pit (Meghalaya) [33]. Figure 3 shows the ethnic preparations made from S. androgynus from different states of India. S. androgynus is one species from the genus which is popular as a leafy vegetable and is used for preparing food items in different corners of the world [32]. Various consumption and cooking methods including salads, soup, curry, mixing with egg and rice, stir fry, and steam are used [32, 33]. The edible portions of the plant include young shoots, tips and leaves. In India, the Muthuvan tribes in the Idukki district of Kerala state and rural people of South Karnataka state consume tender shoots and leaves of the plant [34]. In the state of Kerala, India, it is widely consumed as a major leafy vegetable by the Malayali population. Records state that the plants were introduced to Kerala from Malaysia in 1953 hence they are popular as Malay cheera [35].

The general recipe of preparation of $S$. androgynus leaves in Kerala is shown in Fig. 4. The compound leaves of the plants are used for cooking. After chopping the leaves, chopped onion, chilli, grated coconut and garlic are added along with the leaves for more taste and flavour. Coconut oil and mustard are used for stir-frying. The stir-fry method is used for cooking after adding sufficient salt and turmeric powder. It is usually consumed as a side dish and served with boiled rice. The ethnic groups of Arunachal Pradesh, India also consume the leaves as cooked vegetables [36].

The young leaves and shoots are eaten by people of the Philippines in a method similar to the preparation of Moringa oleifera [37]. Ogle et al. [38] reported that consumption of the $S$. androgynus contributed to significant micronutrient security among the women at the time of flood and rainy season in the Mekong delta, Vietnam. People of Vietnam make soup of the leaves by mixing it with meats such as dried shrimp, crab and minced pork. At the same time, in Malaysia, it is commonly stir-fried with eggs and dried anchovies [33]. In Japan, the leaves and short tips are exported as tropical asparagus [33]. In Malaysian multi-racial cultures, these vegetables are usually eaten raw as a salad which 


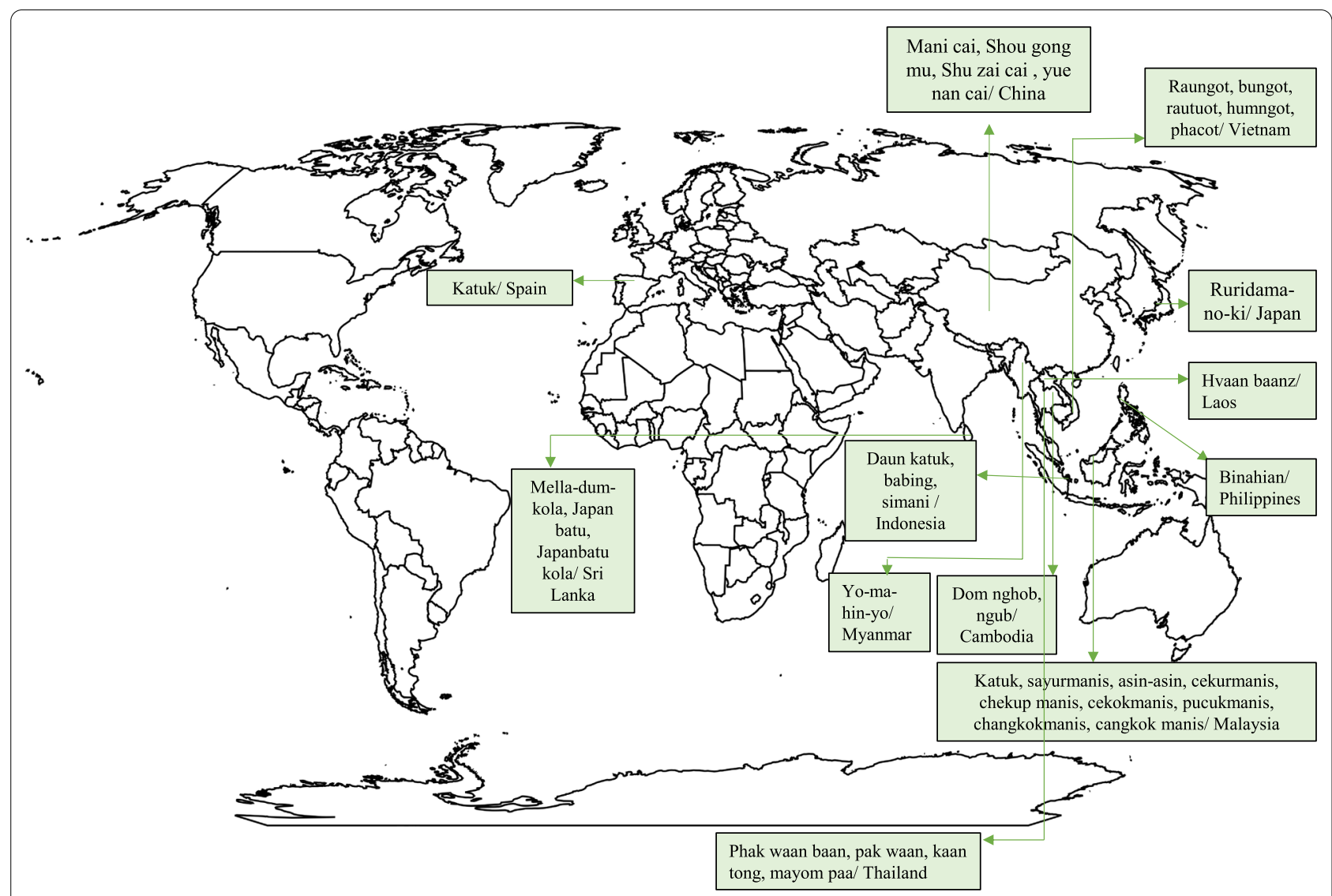

Fig. 2 Map showing ethnic names of leafy vegetable cuisines of S. androgynus in various countries of the world

is known as a cekur manis and ulam [33]. The other species that are consumed as vegetables are $S$. bacciformis, S. macranthus, S. rhamnoides, S. thorelii in Southeast and East Asian countries such as Thailand and China [12]. The leaves and mericarp of S. macranthus are edible [12]. The fruits and leaves of S. rhamnoides are consumed in Thailand [7]. Traditional modes of preparation and consumption of the edible part of genus Sauropus are given in Table 1.

It is not only popular for its nutritional properties, but also for its therapeutic potential [39-43]. It is used to cure several ailments such as fever, urinary problems, ulcers, pain relief, malaria and interestingly they are used to increase the production of breast milk in feeding mothers in various corners of the world [24, 44, 45]. In South Asian countries, it is used as a slimming agent which indicates its anti-obesity activity [46]. S. androgynus have several phytochemicals such as resins, saponins, flavonoids, glycosides, catechol, acidic compounds, tannins, alkaloids, sterols, terpenoids, phenols and cardiac glycosides [47, 48]. Besides nutritional and therapeutic potential, this plant is reported to contain $18-20 \%$ of fatty acids which suggest its potential to be used as biofuel feedstock [49]. The ability of S. androgynus to grow in heavy metal-containing soil points towards its ecological importance of phytoremediation [50].

Few other species of Sauropus such as S. androgynus, $S$. bacciformis, S. compressus, S. macranthus, S. rhamnoides and $S$. thorelii are also used for medicinal and nutritional purposes. S. bacciformis is a subshrub or herb which grows up to the height of $60 \mathrm{~cm}$ tall, monoecious, erect, prostrate or diffuse and glabrous entirely, solitary stems, and several branches from the base [51]. Indian people use this multivitamin plant to cure pyrexia and to treat diseases related to the urinary system [52]. S. bacciformis L. is used for indigestion, leaves of this plant ground along with Piper betle and then orally administered to children for 2 days [53]. Fresh leaves of $S$. compressus Müll. Arg. is used to treat retained placenta, and mouthwash is prepared from the fresh leaves with honey [54]. Leaves are used as poultry and cattle feed [55]. It is also used as an ornamental plant [56]. S. macranthus Hassk. is also edible, but it is the least popular species in the genus. Its leaves and mericarp are edible. It is used as an ornamental plant in Java [7]. S. rhamnoides Blume is edible and found in Thailand, Malaysia, India, Sumatra and the 


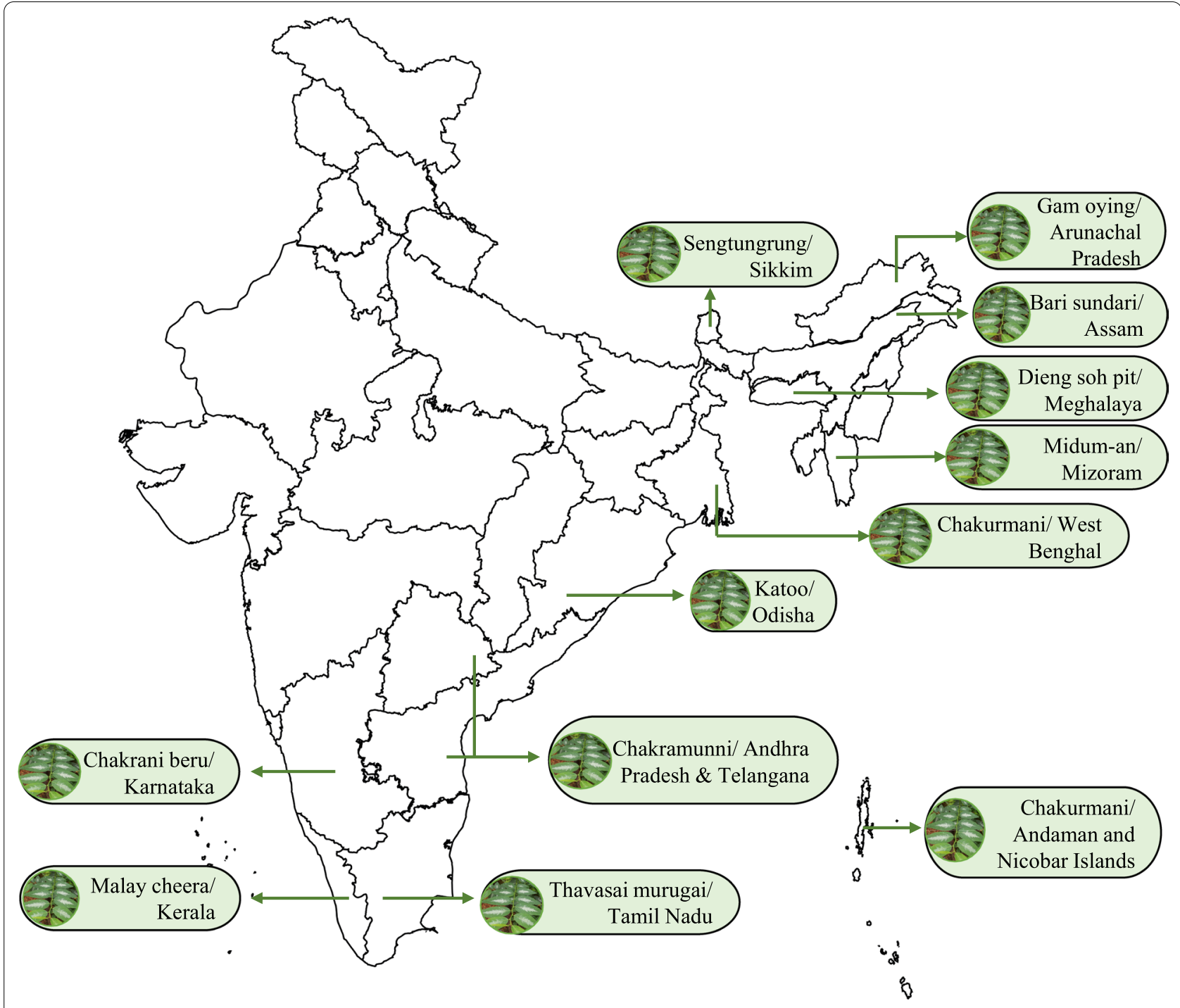

Fig. 3 Map showing ethnic names of ethnic leafy vegetables of S. androgynus in various states of India

Philippines. Its fruits and leaves are consumed [7]. The $S$. thorelii Beille is endemic to Laos and its leaves are used for cooking and flowers are used for fragrance [7].

\section{Nutritional value}

\section{Nutritional components}

The studies on nutritional composition help to reveal the nutritive capacity of edible plants. Extensive research on various major and minor nutrients are required to screen the nutritional profile of a plant. Exploration of edible value of the plants from the genus Sauropus is comparatively less and majority of the research is centralised on $S$. androgynus species. S. androgynus is also called a 'multigreen vegetable' because of its high nutritional value and vitamin quantity in comparison with other vegetable crops $[6,60]$. S. androgynus is a rich source of vitamin A and $C$, protein, calcium and carbohydrates in comparison with other leafy vegetables such as amaranth and drumstick leaves [61]. It has been proved that the concentration of water-soluble vitamins is higher in S. androgynus leaves than fat-soluble vitamins [62]. The fully matured leaves of S. androgynus are recognised as a rich source of $\beta$-carotene. Studies reveal that they are also rich in fatsoluble vitamin $E$ which have antioxidant properties [62]. A comparative study was performed to understand the difference between the nutritional composition of basal whorl leaves and terminal whorl leaves of $S$. androgynus by Naveena et al. [61] and found that basal whorl leaves are more enriched with nutrients than terminal whorl leaves. They also reported that there was a significant 


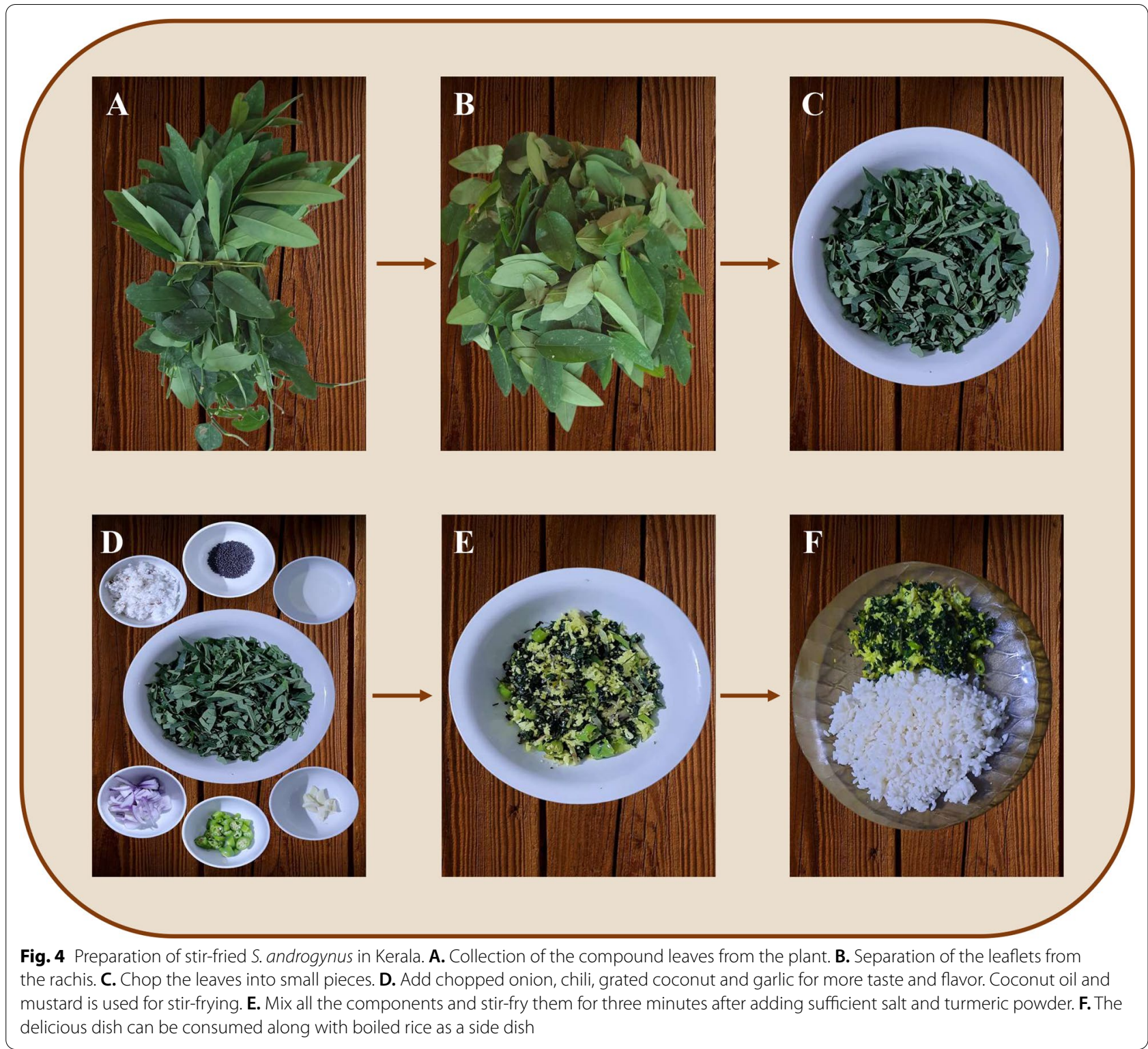

elevation in the quantity of nutrients such as proteins, carbohydrates, calcium and vitamin $\mathrm{C}$ from day 60 to day 120 which suggests the difference in nutrient accumulation inside plant organs according to their developmental stages [61].

Elemental composition studies showed that fully matured leaves of $S$. androgynus have elevated quantities of iron and zinc [62]. Calcium content of fully matured leaves is also higher than the tender leaves. Iron is an abundant element found in this plant and has a high concentration that reaches greater than $100 \mathrm{mg} /$ $\mathrm{kg}$ [63]. The investigation by Santoso et al. [64] shows that the addition of turmeric and garlic to fermented $S$. androgynus-bay leaves enhanced methionine, arginine, tyrosine, aspartic acid, histidine, valine and total amino acid in broiler chicken meat. They hypothesised that different sulphur compounds (S-allyl cysteine, allicin, diallyl disulfide) diversity of garlic can induce insulin production, which results in increased uptake of blood amino acids to muscle. It also induces the synthesis of methionine by bacteria in the stomach. They also suggest that the synergic interaction between turmeric and garlic along with fermented S. androgynus increased the amino acids such as arginine in the meat of broiler chicken because individual supplementation of these things did not make any impactful changes in the amino acid composition inside the organism. The study proved the possibility of increasing the nutritional value of food 
Table 1 Traditional food systems that are based on the S. androgynus

\begin{tabular}{|c|c|c|}
\hline Country/State/Region/Tribal/indigenous community & Part used and mode of preparation & Reference(s) \\
\hline \multicolumn{3}{|l|}{ S. androgynus } \\
\hline $\begin{array}{l}\text { Natives of Ilocos Norte, Palawan and South Central Mindanao- } \\
\text { Philippines }\end{array}$ & Young leaves and shoots are cooked & {$[37]$} \\
\hline Indigenous community in the Solomon Islands, northern Australia & Curry is prepared from their leaves & {$[57]$} \\
\hline Villagers of Mekong Delta, Vietnam & Consumed as leafy vegetables & {$[38]$} \\
\hline Throughout Thailand & $\begin{array}{l}\text { Shoot, fruits and leaves are eaten raw and cooked. Soup is also } \\
\text { prepared }\end{array}$ & [7] \\
\hline Malaysia & Leaves are eaten raw and sometimes included in salads also & {$[33]$} \\
\hline Karbi tribes in Assam, India & Curry is made with leaves & {$[58]$} \\
\hline Muthuvan tribes In Kerala, India & Tender leaves are cooked and consumed & {$[34]$} \\
\hline \multicolumn{3}{|l|}{ S. macranthus } \\
\hline Southeast Asian countries & Leaves and mericarp are consumed & [7] \\
\hline \multicolumn{3}{|l|}{ S. rhamnoside } \\
\hline Thailand & Fruits and leaves are consumed & {$[7]$} \\
\hline \multicolumn{3}{|l|}{ S. thorelii } \\
\hline Endemic to Laos & Leaves are cooked and consumed & {$[7]$} \\
\hline \multicolumn{3}{|l|}{ S. spatulifolius } \\
\hline $\begin{array}{l}\text { South China } \\
\text { Guangdong region }\end{array}$ & $\begin{array}{l}\text { Herbal tea is prepared with an aqueous decoction of the whole } \\
\text { plant }\end{array}$ & [59] \\
\hline
\end{tabular}

supplements with the combination of such traditional plants and plant-derived products. Detailed nutritional composition of $S$. androgynus with their biological activities is presented in Table 2.

\section{Bioaccessibility of nutrients}

The cooking procedure induces significant alterations in the nutritional, sensory and structural composition of various food components [85]. The bioaccessibility of the nutritional components is highly dependent on the cooking methods [86]. S. androgynus is a good source of $\beta$-carotene (5.6 mg/100 g), but Padmavathi and Rao [32] reported the degradation of protein and beta-carotene at the time of heating of their leaves. Arumsari et al. [87] investigated the influence of various cooking methods, such as microwave cooking, boiling, and raw consumption and palm oil addition on the bioaccessibility of $\beta$-carotene from $S$. androgynus. They reported that the $\beta$-carotene content in microwave digested and boiled leaves were less than in raw leaves, but the addition of palm oil increased bioaccessible $\beta$-carotene content in all cooking methods tested by them. Azima et al. [88] investigated the influence of different cooking methods on the phenol, vitamin $\mathrm{C}, \mathrm{Fe}, \mathrm{Mg}$ and $\mathrm{Zn}$ content of $S$. androgynus leaves. This study reported that stir-frying cooking increased the content of $\mathrm{Zn}, \mathrm{Mg}$, Fe and phenol in the leaves, while it reduced vitamin $C$ content. The boiling and steaming method resulted in the reduction of these components. From the studies, it is clear the mode of consumption or mode of cooking have a crucial role in the contribution of nutrients to consumers from the plant.

\section{Food fortification with Sauropus androgynus}

Food fortification is an important method to enrich the foods deficient in a particular nutrient. The method of food fortification is helpful for the reduction of micronutrient deficiencies of the populations effectively [89]. $S$. androgynus have been used for the fortification of staple food [90, 91]. Hasrini et al. [90] explored the possibility of nutritional fortification of cassava flour cookies with $S$. androgynus along with $M$. oleifera and Brassica oleracea, because of lack of minerals, fat and protein content in cassava flour modified cookies. Fortification of the cookies with these vegetables enriched the nutritional profile of the cookies more than pure cassava flour. Among them, cookies fortified with $S$. androgynus displayed high mineral content $(\mathrm{Ca}, \mathrm{K}, \mathrm{Mg}$ ) after $B$. oleracea fortified cookies. Similarly, sago noodles are also a carbohydraterich staple food in the area of Riau Province, Indonesia. But they lack other essential nutrients such as proteins. Research by Dewita et al. [91] attempted to fortify the sago noodles with fish oils, fish proteins. S. androgynus was also included as a vegetable source of vitamins and fibre. Finally, they reported highly nutritional rich noodles compared to raw sago noodles. Further studies must be conducted to fortify the foods with S. androgynus. 
Table 2 Nutritional composition of S. androgynous

\begin{tabular}{|c|c|c|}
\hline Constituents & Quantity (references) & Function (references) \\
\hline \multicolumn{3}{|l|}{ Macronutrients } \\
\hline Proteins & $\begin{array}{l}10.83 \%[65] ; 15.8 \mathrm{~g} / 100 \mathrm{~g}[66] ; 5.2 \%[20] ; 3.04 \%[67] ; \\
8.31 \mathrm{~g} / 100 \mathrm{~g}[68] ; 7.4 \mathrm{~g} / 100 \mathrm{~g}[6] ; 15.0 \%[64]\end{array}$ & Obesity control by elevating high-density lipoprotein (HDL) cholesterol [69] \\
\hline Carbohydrates & $54.5 \mathrm{~g} / 100 \mathrm{~g}[66]$ & Carbohydrates in our body maintain the energy potential [70] \\
\hline Chlorophyll & $14.43 \pm 0.16 \mu \mathrm{g} / \mathrm{mL}[71]$ & Antioxidant agent [72] \\
\hline Fatty acids & $62.92 \%[65]$ & Act as an energy donor complex, interconnected systems [73] \\
\hline Crude fibre & $1.87 \%$ [65]; $36.0 \mathrm{~g} / 100 \mathrm{~g} \mathrm{[66];} \mathrm{1.75 \%} \mathrm{[20];} 1.07 \%$ [67] & Enhances food digestion [70] \\
\hline Crude fat & $0.85 \%$ [65]; 0.58\% [20].; $4.0 \mathrm{~g} / 100 \mathrm{~g} \mathrm{[66];} \mathrm{1.07 \%} \mathrm{[67]}$ & Helps in fat-soluble vitamin absorption [70] \\
\hline \multicolumn{3}{|l|}{ Micronutrients } \\
\hline $\mathrm{Fe}$ & $8.8 \mathrm{mg} / 100 \mathrm{~g}[32] ; 13.5 \mathrm{mg} / 100 \mathrm{~g}[74]$ & Participate in oxygen transport [75] \\
\hline $\mathrm{Zn}$ & $15.9 \mathrm{~g} / 100 \mathrm{~g}[76]$ & Growth, development and defense [77] \\
\hline $\mathrm{Mn}$ & $664.9 \mathrm{mg} / 100 \mathrm{~g}[33]$ & Plant growth and development [78] \\
\hline $\mathrm{Cu}$ & $768.7 \mathrm{mg} / 100 \mathrm{~g}[76]$ & Ensure cellular functions [79] \\
\hline $\mathrm{Mg}$ & $664.9 \mathrm{mg} / 100 \mathrm{~g}[76]$ & Activates enzymes [80] \\
\hline K & $\begin{array}{l}45.7 \mathrm{mg} / 100 \mathrm{~g}[76] \\
45.70 \mathrm{mg} / 100 \mathrm{~g}[20]\end{array}$ & Cofactor that functions in protein synthesis [80] \\
\hline $\mathrm{P}$ & $543 \mathrm{mg} / 100 \mathrm{~g}[32]$ & $\begin{array}{l}\text { Major constituent in phospholipids, nucleic acids, adenosine triphosphate (ATP), } \\
\text { coenzymes [80] }\end{array}$ \\
\hline $\mathrm{Ca}$ & $2.8 \%[74] ; 118.8 \mathrm{mg} / 100 \mathrm{~g}[74]$ & $\begin{array}{l}\text { Important information and stability of cell walls and in maintenance of mem- } \\
\text { brane structure and permeability [80] }\end{array}$ \\
\hline Co & 1.62 mg/100 g [76] & Integral part of the structure of vitamin B12 (Cobalamin) [81] \\
\hline Vitamin A & $4.11 \mathrm{mg} / 100 \mathrm{~g}[61]$ & Cancer prevention [82] \\
\hline Vitamin C & $\begin{array}{l}244 \mathrm{mg} / 100 \mathrm{~g}[32] \\
56.1 \mathrm{mg} / 100 \mathrm{~g}[74]\end{array}$ & Essential for mental and physical development of the body [33] \\
\hline Vitamin E & $17.8 \mathrm{mg} / 100 \mathrm{~g}[62]$ & Inhibition of platelet aggregation [83] \\
\hline Carotene & $5600 \mu \mathrm{g} / 100 \mathrm{~g}[32]$ & Reduce cancers and eye disease risk [84] \\
\hline
\end{tabular}

\section{Ethnomedicinal importance of Sauropus androgynus}

Plants play an important role in the life of humans in all stages of their life span [92]. Our ancestors have been dependent on plants for their various therapeutic uses since time immemorial [93]. The plant-derived medicinal formulations are used against various primary disorders by different populations around the world [93]. The initial stage of drug discovery is the documentation of traditionally used medicinal plants and other materials [94]. But the knowledge regarding traditional medicine is vanishing from generation to generation due to the development of modern treatment methods and due to the influence of urbanisation [94]. Therefore investigation of traditional ethnomedicinal knowledge of plants is very important and it can help to promote the conservation of the plants and provide an opportunity to validate the medicinal use [95]. S. androgynus possesses several therapeutic uses [76]. S. androgynus plays a major role in traditional medicinal systems for curing some ailments as it is a good source of fatty acids, polyphenols, and flavonoids [20]. Lee et al. [96] investigated the importance of $S$. androgynus in the Chinese herbal medicinal system and reported that the villagers depend on the treatments of various ailments such as laryngitis, cough, hepatitis, constipation, blurred vision and enteritis. Besides Plectranthus amboinicus, S. androgynus is used to increase breast milk production [97]. In Taiwan, people use this plant as a slimming agent to tackle obesity [6]. 3-O- $\beta$ D-glucosyl-(1-6)- $\beta$-D-glucosyl-kaempferol (GGK) is the chemical compound found in Sauropus plants which can act as an antiobesity agent [98]. S. androgynus increases the fat content of milk, therefore providing S. androgynus leaves along with gamal leaves to cows can improve the fat content of the cow milk [99]. In another study, it was reported that the leaves of the $S$. bacciformis are used for indigestion, especially in children. The leaves are ground along with Piper betle and then orally administered for 2 days for proper digestion [53]. Fresh leaves of S. compressus are used for treating retained placenta [54]. The ethnomedicinal uses of $S$. androgynus in different countries of the world and different states of India are shown in Tables 3 and 4 respectively. More ethnomedicinal studies are required to screen the ethnomedicinal uses of $S$. androgynus from other parts of the world. The validation of its reported ethnomedicinal properties should 
Table 3 Ethnomedicinal uses of S. androgynus across different countries

\begin{tabular}{|c|c|c|c|c|c|}
\hline $\begin{array}{l}\text { Country/state/ } \\
\text { region/district }\end{array}$ & Common name & Part(s) used & Ethnomedicinal use(s) & Mode of usage & Reference(s) \\
\hline \multicolumn{6}{|l|}{ Asia } \\
\hline \multirow[t]{4}{*}{ Indonesia } & Katuk & Leaves & Uterotonic agent & Fresh leaves and roots & [20] \\
\hline & & & Febrifuge & $\begin{array}{l}\text { Leaves are blended, then put } \\
\text { on the head }\end{array}$ & {$[100]$} \\
\hline & & & Cough & $\begin{array}{l}\text { Leaf extract is mixed with } \\
\text { kencur (Kaempferia galanga L.) } \\
\text { water and then drunk }\end{array}$ & [100] \\
\hline & Kayu manis, daun katuk, katuk & Leaves & $\begin{array}{l}\text { Heartburn, and for cleaning } \\
\text { the blood }\end{array}$ & Leaf decoction & [101] \\
\hline Malaysia & Sayur Manis & Root & $\begin{array}{l}\text { Fever and urinary bladder } \\
\text { complaints }\end{array}$ & Root decoction & {$[20]$} \\
\hline India & $\begin{array}{l}\text { Star gooseberry, Chinese } \\
\text { soppu }\end{array}$ & Root & Diarrhea & Root powder & [102] \\
\hline Thailand & Phak wan ban & Root, leaf & Aphthous ulcer & Boiling to drink & [103] \\
\hline China & Shu zi cai & Leaf & Cough & Leaf extract & [20] \\
\hline Vietnam & phac ot & Leaf, stem and root & fever & & [104] \\
\hline
\end{tabular}

Table 4 Ethnomedicinal uses of S. androgynus in different parts/states of India

\begin{tabular}{|c|c|c|c|c|c|}
\hline States & $\begin{array}{l}\text { Tribal/ community/ sub } \\
\text { area }\end{array}$ & Common name & Part(s) used & Ethnomedicinaluse(s) & References \\
\hline Andaman \& Nicobar Islands & & Chakarmani & Leaf & Vision and skin problems & {$[55,76]$} \\
\hline Assam & Sonowal Kacharis & Bari sundari & Root & $\begin{array}{l}\text { Tongue ailment (Appearance } \\
\text { of white layer on the tongue } \\
\text { of children) }\end{array}$ & {$[55,105]$} \\
\hline \multirow[t]{2}{*}{ Karnataka } & & $\begin{array}{l}\text { Chakrani beru, Chinese } \\
\text { soppu }\end{array}$ & Root & $\begin{array}{l}\text { Maceration of root with } \\
\text { lemon juice and then applied } \\
\text { on the bite (snake bite) }\end{array}$ & {$[55,106]$} \\
\hline & Soliga tribes & Chikrumani & Stem, leaves & $\begin{array}{l}\text { Used to treat diabetes, } \\
\text { inflammations and cough }\end{array}$ & {$[55,106]$} \\
\hline Kerala & $\begin{array}{l}\text { Muthuvan tribes of Idukki } \\
\text { district }\end{array}$ & Malay cheera, elacheera & Whole plant & Increase lactation & {$[55,107]$} \\
\hline Tamil Nadu & Thavasi Murungai & Thavasi murungai & Root & $\begin{array}{l}\text { Decoctions for treating } \\
\text { urinary complaints }\end{array}$ & {$[55,108]$} \\
\hline Arunachal Pradesh & Adi- Minyong tribe & Woein & Leaves & $\begin{array}{l}\text { Leaf decoctions for revital- } \\
\text { izing agents, cooked as } \\
\text { vegetables }\end{array}$ & [109] \\
\hline Mizoram & Mizos & Midum-an & Leaves & Revitalizing agent & {$[110]$} \\
\hline
\end{tabular}

be performed through pharmacological experiments to obtain scientific and reliable evidence.

\section{Bioactive compounds found in S. androgynus}

Bioactive compounds present in plants are important for human health. They are very essential for the human body as they have several bioactivities such as anti-inflammatory, antidiabetic, antioxidant, and antimicrobial activities [111]. Specialised metabolites (earlier known as secondary metabolites) are the major phytochemicals that contribute to the bioactivity of plants
[112]. Plants are the biggest source of medicinally important compounds crucial for discovering novel products and improving drug development. Plant specialised metabolites have gained considerable attention due to their potential for flavours, food additives and pharmaceuticals [113]. Functions of secondary metabolites include inhibition or stimulation of defence and microbial interactions, catalytic activity, signalling and act as structural compounds in various mechanisms in the cell [114]. A variety of specialised metabolites including steroids, flavonoids, fatty acids, alkaloids, tannins and resins 
are found in plants [113]. Plenty of articles are available on the richness of bioactive phytochemicals viz steroids, terpenoids, tannins, alkaloids, phenols, flavonoids, volatile oils and fatty acids in the S. androgynus [47]. Besides major carbohydrates, proteins, lipids, alkaloids, terpenoids and phenolics, they reported important medicinal components such as 1,14-tetradecanediol (antimicrobial activity); 1-octadecyne (antibacterial and anti-inflammatory); 1-hexadecyne (antibacterial); decanoic acid, ethyl ester (nematocide); phytol (anticancerous); $2(1 \mathrm{H})$ naphthalenone, 3,5,6,7,8,8 a-hexahydro 4, 8a-dimethyl-6-(1- methylethenyl) (anti-inflammatory); azulene, aoctahydro-1,4-dimethyl7-(1-methylethenyl)-, [1- methylethenyl) and squalene with several pharmacological properties.

Andarwulan et al. [68] showed that among 11 selected Indonesian vegetables, $S$. androgynus showed the highest amount of flavonoid content, which is an indication of the antioxidant property of the plant. The hydroxyl group in the flavonoid compound facilitates free radical scavenging activity and helps in the induction of antioxidant defence mechanisms inside the human body [115]. The compounds are capable of stimulating the human protective enzyme system [115]. Besides antioxidant activity, the compounds perform inactivation of cell transport proteins, adhesins and enzymes of microbes, hence they display antimicrobial activity [116]. They are effective against viral enzymes too, hence they show antiviral activity [117]. Flavonoids are inhibitors of the phosphodiesterase enzyme (an enzyme that is involved in cell activation), and they decelerate the inflammation procedure [115]. Flavonoids are well known for retarding the action of several carcinogenic conditions [118]. Since the plant $S$. androgynus contains a good amount of flavonoids, they promise their effectiveness in various pharmacological activities mentioned above.

The detailed and prime metabolic fingerprinting of $S$. androgynus was performed by Yunita et al. [21] using Gas Chromatography-Mass Spectroscopy (GC-MS) on the leaf methanol extract from six geographical regions. Their study found wide variation in the composition of metabolites and further revealed that major portion of the $S$. androgynus metabolites is dominated by various fatty acids such as palmitic acid, myristic acid, methylstearate and methyl-linoleic subsequently followed by isophytol and phytols. The plant-based fatty acids are effective against the reduction of cardiovascular diseases by modifying the blood lipid profile and activating several anti-inflammatory pathways. Plant-based fatty acids interact with the gut microbiome and translocate the lipopolysaccharides too [119]. The same study revealed the presence of vitamin $\mathrm{E}$ in a comparatively higher quantity in the samples. Plants usually synthesise $\alpha, \beta$, $\gamma, \cdot$ tocopherols from homogentisic acids and these compounds are excellent in free radical scavenging activity [83]. They display anticancer activity by activating p53 tumour suppressor gene and heat shock proteins. Vitamin E also downregulates the expression of mutated p53 proteins and has anti-angiogenic activity by blocking the transformation of alpha growth factors [120]. It was reported that vitamin $E$ is capable of boosting the human immune system by enhancing phagocytic activity and cellular immune responses [83]. Since $S$. androgynus is rich in vitamin $E$, they can be included in the food system to fortify the diet of deficient people. Because vitamin $\mathrm{E}$ deficiency can cause problems related to the immune system, vision, muscle power and body balance [83]. Similarly, a metabolomic study done with Fourier Transform Infra-Red spectroscopy (FTIR) revealed that S. androgynous leaves contain carboxyl, alkene, amine salt, sulfone, amines and alkyl aryl ether [56].

The non-narcotic alkaloid compound papaverine was reported in S. androgynus plants. The compounds are effective inhibitors of phosphodiesterase and are used for the treatment of erectile dysfunction and vasospasm. The compound is also recognised for its anticancer activity [121]. The papaverine content in S. androgynus leaves is reported to increase oxytocin and prolactin production, which are the two main hormones in milk production [122]. The experiments involving mice supplemented separately with younger and mature leaves of $S$. androgynus revealed that concentration of oxytocin and prolactin increased when mice were supplemented with mature leaves of $S$. androgynus [122]. The quantity of papaverine present in the fresh leaves of S. androgynus is $580 \mathrm{mg} / 100 \mathrm{~g}$ which has the capacity to act as an antispasmodic drug [32]. In a human-based study, it has been proven that the leaf extracts of $S$. androgynus plants boost the mothers' breast milk production [55], this can be because of the presence of papaverine in the leaves.

A new steroid 20-hydroxyisofucosterol (stigmasta5,24(28)-diene-3 $3,20 \beta$-diol) was reported by Zhang et al. [123] from S. androgynus. The pharmacological studies of the extract showed that they have moderate levels of cytotoxic activities and it can inhibit the activity of the alpha-melanocyte-stimulating hormone. Alpha-melanocyte hormone has a crucial role in the control of several metabolism [124]. Recently Huong et al. [125] discovered three new glycosides viz. aurobaccioside A, saurobaccioside B, saurobaccioside $C$ from the whole plant of $S$. bacciformis and displayed significant cytotoxic activity against cancerous cell lines. Another bioactive compound reported from two Sauropus species was eudesmin. Sawasdee et al. [126] reported eudesmin from the leaves of $S$. thorelii and S. bicolor. Eudesmin is popular for its antitumor, anti-inflammatory and anticonvulsant properties 
[127, 128]. Similarly, a novel component named sauropurostratic acid was reported from the plant $S$. rostratu by Wei et al. [129]. In the same study, they have extracted and identified a total of 19 other compounds and $\beta$-sitosterol, niacinamide, quercetin, mannitol, aurantiamide acetate and kaempferol were reported for the first time. The $\beta$-sitosterol has hypolipidemic activity since it has structural similarity with cholesterol and acts as a competitive inhibitor for cholesterol during absorption [130]. Niacinamide is an amide of vitamin B3 and is effectively used for the treatment of skin pigmentation related problems. It acts by blocking the migration of melanosomes from melanocytes to keratinocytes that suppresses skin pigmentation [131]. The phytochemical quercetin belongs to the group flavonoids and it also shows functions similar to flavonoids as we discussed earlier. The compound mannitol is a harmless natural sweetener in comparison with glucose and sucrose. Kaempferol is another antioxidative polyphenol with anticancer activity. Kaempferol modulates several proteins related to inflammation, angiogenesis, apoptosis and metastasis [132]. Wang et al. [133] detected three new hexose carbohydrate derivatives from $S$. rostratu plant, namely, Butyl 3,6- anhydro-2-deoxy-b-D-arabino-hexofuranoside, Butyl 3,6-anhydro-2-deoxy-b-D-glucofuranoside and Methyl (1R,3R,4S,5R)-3,6-anhydro-2-deoxyhexofuranoside. These are novel compounds detected from the plants and more extensive studies are required about these compounds. The detection of the bioactive compounds strengthens the validation of bioactivities of $S$. androgynus plants and provides evidence for their ethnomedicinal properties. Phytochemicals present in $S$. androgynus, with their quantities and reported biological activities are shown in Table 5.

\section{Pharmacology of Sauropus androgynus}

Ethnomedicinal uses of plants are nowadays increasingly validated using pharmacological studies involving various in vivo and in vitro models [161]. As discussed in the previous section, $S$. androgynus contains some of the very important phytochemicals with proven medicinal properties. The medicinal plants exert their bioactivities through the bioactive compounds present in them. The extraction method, dosage and mode of application is very crucial in determining the efficiency of the treatment which can be achieved through pharmacological studies [162]. Some of the ethnomedicinal properties of $S$. androgynus are also recently validated using modern pharmacological studies. Pharmacological studies are also crucial for the evaluation of toxicity or potential side effects of any extract consumed by the people for the treatments of their diseases. Several researchers have reported multiple bioactivities of $S$. androgynus using pharmacological studies [163-167]. Various bioactivities of $S$. androgynus are discussed in the subsequent sections and are summarised in Fig. 5.

\section{Antioxidant potential}

Antioxidants aid in the neutralisation of free radicals and reactive oxygen species (ROS) inside the cell [168]. Exposure to pollutants, sunlight, UV radiation, X-rays, smoke (both tobacco and automobile exhaust), and ozone by humans can result in the generation of reactive oxygen species [169]. They are highly reactive and unstable and cause damage to the nucleic acids, lipids, proteins and carbohydrates in the cell, which consequently results in the development of degenerative diseases [170]. Therefore the proper spatial and temporal elimination/ neutralisation of ROS is crucial in the day to day life of humans, which is carried out by the antioxidant compounds $[169,170]$. The plant-based antioxidants are the best and most popular as they scavenge the free radicals inside the cells effectively and boost the defence mechanism by the endogenous antioxidants [171]. It was proved that supplementation of exogenous plant-based antioxidants are effective for the treatment of diseases due to ROS and it boosts the endogenous free radical scavenging machinery [172]. Antioxidants are effective as antiageing and anti-inflammatory agents. These compounds have multiple applications in different areas [173]. Antioxidants are added to many food items for enriching the health benefits of the diet [173]. Natural antioxidants are found in foods and prevent the sourness, disruption and colour change of the food [173]. They have high stability and low volatility, and a significant role in maintaining the level of nutrients, colour, taste, texture, freshness and aroma [174]. The common natural antioxidants present in plants include vitamin $\mathrm{C}$, chlorophyll a, chlorophyll b, carotenoid, flavonoids and polyphenols [173]. Carotenoids are essential for the human body since they cannot be synthesised [33]. Flavonoids are important dietary antioxidants that are well known for their role at different developmental stages of malignant tumours by protecting DNA. It inactivates carcinogens and inhibits the mutagenic gene and enzyme expression [33]. Polyphenols are important metabolites in nature. They have protective effects on human carcinogenesis, memory and cognitive function, then some other effects such as age-related neurological dysfunctions, and ulcers [33]. Vitamins are very important for the common metabolic functions, immune responses and mental and physical development [33]. Various in vitro assays such as DPPH radical scavenging, ABTS radical scavenging, FRAP helps to understand the antioxidant activity of plant extracts which is helpful in preventing various oxidative stresses [175]. 
Table 5 Main phytochemicals found in S. androgynus with their reported medicinal properties

\begin{tabular}{|c|c|c|c|}
\hline $\begin{array}{l}\text { Name of the } \\
\text { compound }\end{array}$ & $\begin{array}{l}\text { Quantity } \\
\text { (references) }\end{array}$ & 2 D Structure* & $\begin{array}{l}\text { Biological activity } \\
\text { (references) }\end{array}$ \\
\hline Decanoic acid & $0.57 \%[47]$ & & Nematocide [47] \\
\hline Phytol & $13.08 \%[134]$ & & $\begin{array}{l}\text { Cancer prevention, } \\
\text { Autoimmune } \\
\text { response [47]. } \\
\text { Antibacterial agent } \\
\text { [135]. } \\
\text { Antioxidant [136]. }\end{array}$ \\
\hline Squalene & $8.06 \%$ [47]. & $\varphi$ & $\begin{array}{l}\text { Antibacterial, } \\
\text { Antitumour, } \\
\text { Anticancer [47]. } \\
\text { Prevention, } \\
\text { Chemopreventive, } \\
\text { Immunostimulant, } \\
\text { Lipoxygenase } \\
\text { inhibitor [135]. } \\
\text { Antioxidant [136]. }\end{array}$ \\
\hline Neophytadiene & $2.92 \%[135]$ & & $\begin{array}{l}\text { Bactericidal, } \\
\text { antifungal, } \\
\text { antipyretic, } \\
\text { analgesic, } \\
\text { antioxidant, } \\
\text { antihelminthic } \\
\text { [135]. }\end{array}$ \\
\hline Solanesol & $4.09 \%[135]$. & arererererer & $\begin{array}{l}\text { Antihypersensitive, } \\
\text { antimicrobial, } \\
\text { cardiac stimulant, } \\
\text { antitumor, lipid } \\
\text { antioxidant, anti- } \\
\text { inflammatory and } \\
\text { antiulcer [135]. }\end{array}$ \\
\hline Terpenoids & $4.03 \%[65]$. & & $\begin{array}{l}\text { Abiotic stress } \\
\text { protection [137]. }\end{array}$ \\
\hline
\end{tabular}


Table 5 (continued)

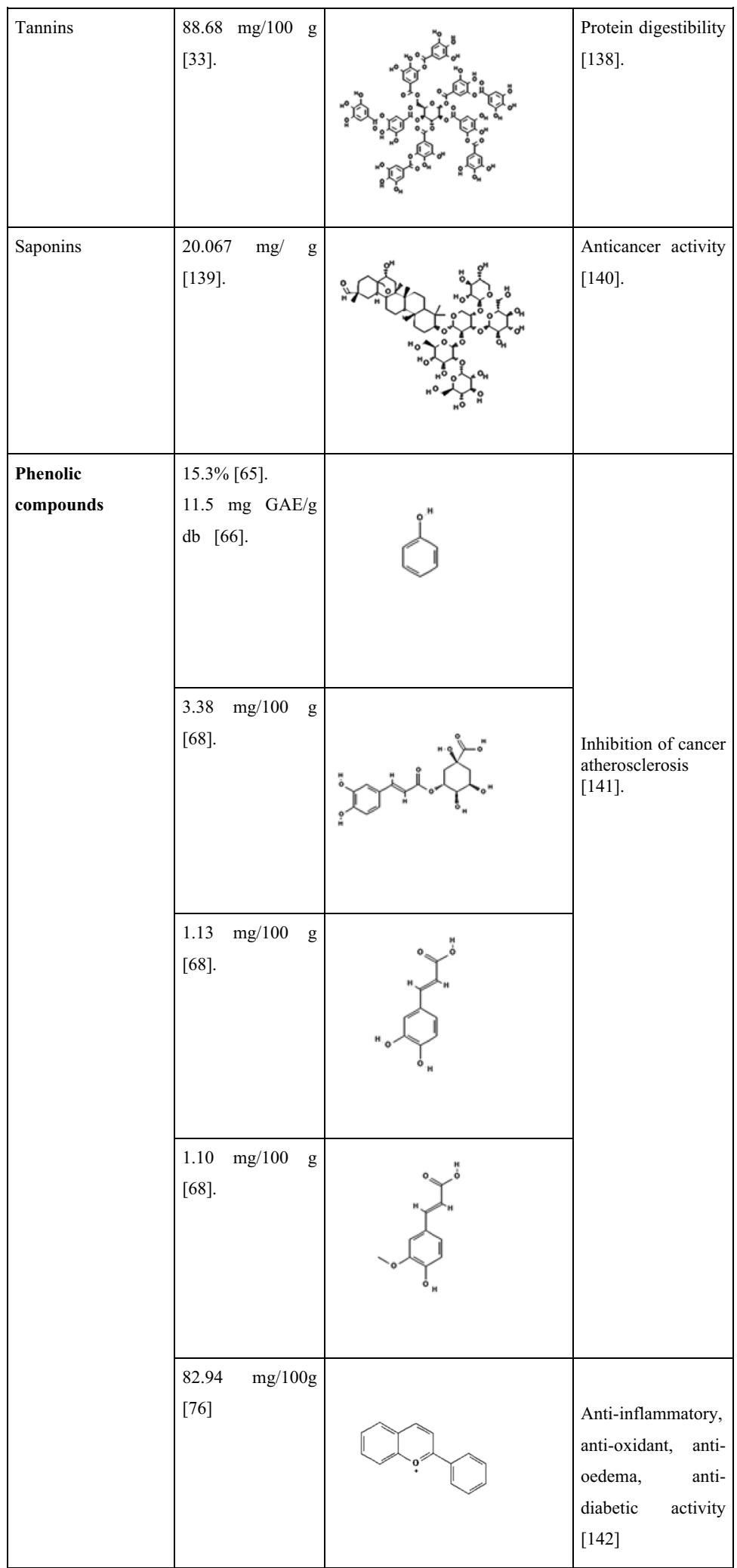


Table 5 (continued)

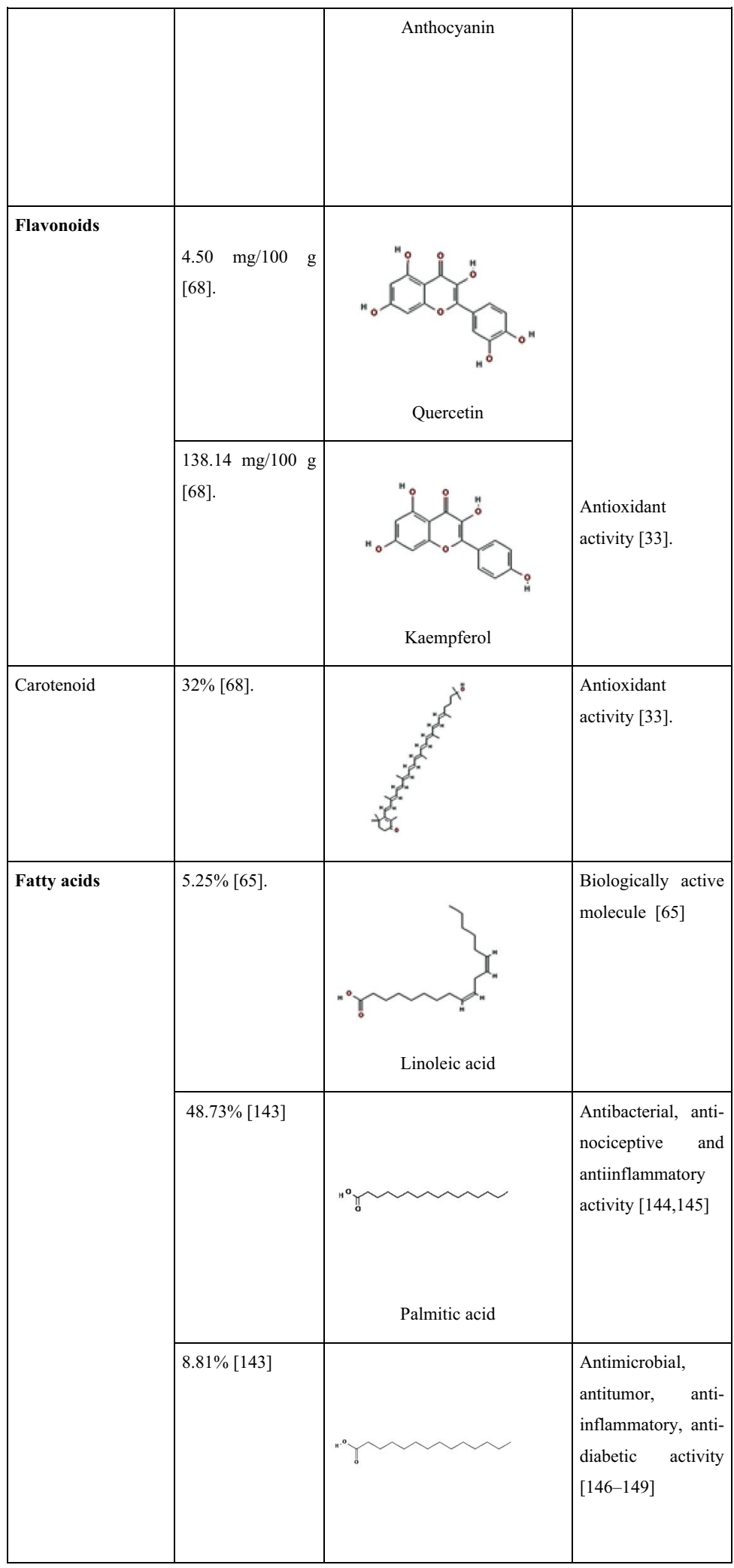


Table 5 (continued)

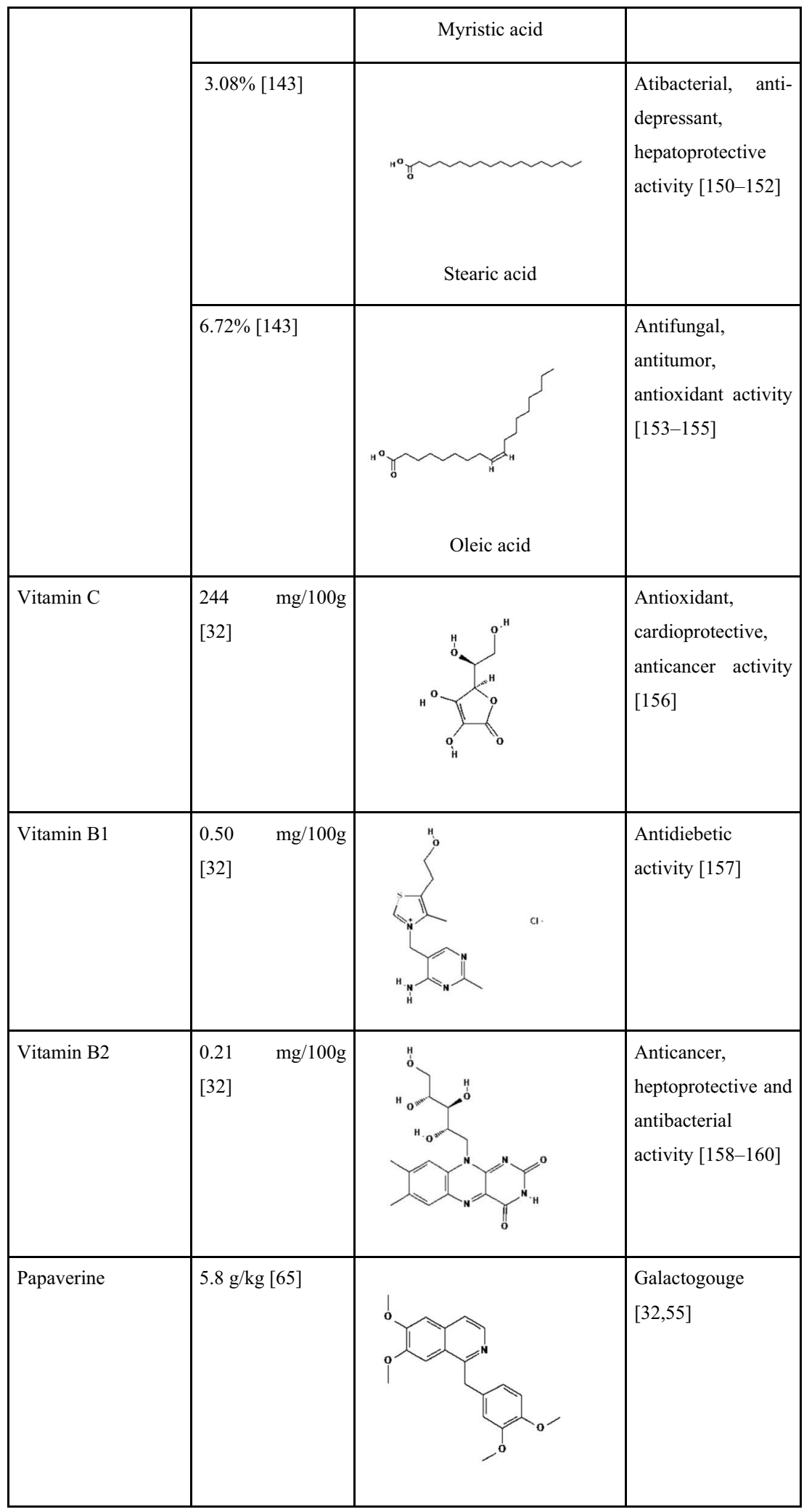

*2D structures are taken from PubChem (https://pubchem.ncbi.nlm.nih.gov/) 


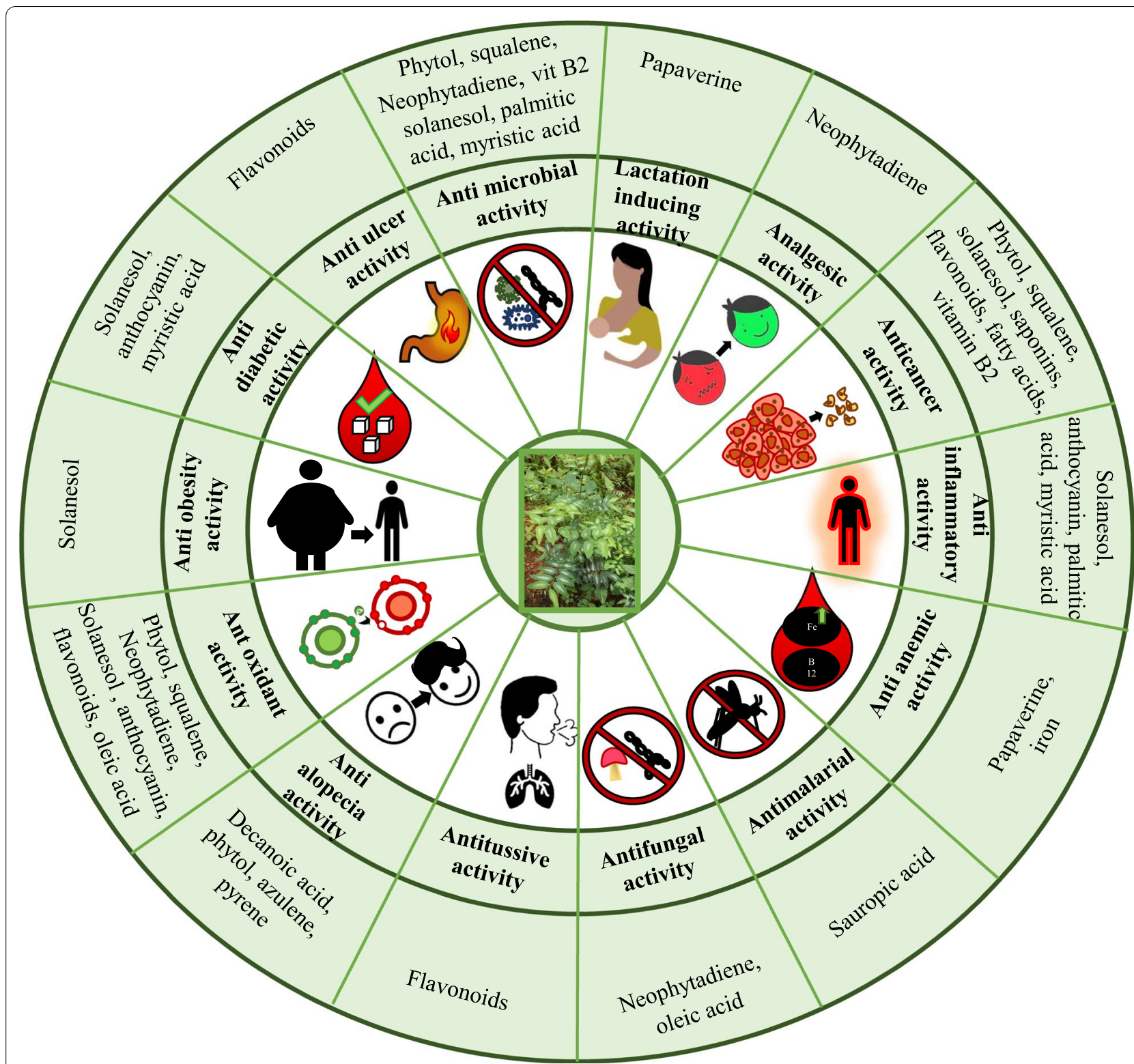

Fig. 5 Various bioactivities and bioactive compounds of S. androgynus

S. androgynus shows antioxidant properties and is rich in flavonoids which is one of the important natural antioxidants $[68,136]$. According to the study conducted by Ermi Hikmawanti et al. [176], S. androgynus ethanolic leaf extract (50\%) shows the best and potential antioxidant activity. Pasta prepared with Sauropus leaves reduces lipid peroxidation [177]. Polyphenols from leaf extract of Sauropus are also a good source of free radical activity and can be used to treat diseases developed through the action of free radicals [134]. Studies conducted by Nguyen et al. [71] showed significant 2,2-diphenyl-1-picryl-hydrazyl-hydrate (DPPH) scavenging activity of the chlorophyll extracted in $90 \%$ acetone from the S. androgynus plant. The experiment conducted by Badami and Channabasavaraj [178] also displayed antioxidant properties against the ABTS free radicals.

Besides flavonoids and polyphenols, S. androgynus is rich in Coenzyme Q10 (CoQ10) which acts as a strong antioxidant. Kettawan et al. [42] analysed the plasma antioxidant activity of $S$. androgynus leaf powder in male Wistar rats and checked the absorption and quantity of CoQ10 after the stir-frying the leaves. The study reported that the stir-frying procedure does not affect the quantity of CoQ10 in the plants and showed significant free 
radical scavenging activity in the ferric reducing antioxidant power assay (FRAP), oxygen radical absorbance capacity and DPPH free radical scavenging method. The antioxidant activity of tissue cultured shoots of $S$. androgynus was explored by Petchang [179]. They have accelerated the antioxidant activity with the treatment of ultraviolet $\mathrm{C}$ radiation and triggered the production of secondary metabolites by the addition of 6-benzyladenine in the Murashige and Skoog medium. They have observed strong antioxidant activity using both the enzymatic (with the aid of enzymes superoxide dismutase and glutathione peroxidase) and non-enzymatic activity (with ABTS, DPPH and FRAP assay). The antioxidant activity S. spatulifolius was performed by Wei et al. [129]. The antioxidant activity of $S$. spatulifolius against acute lung injury in mice induced through lipopolysaccharide was analysed and they found that ethanol extract of the leaf is able to accelerate superoxide dismutase activity in the mice. The analysis revealed the natural free radical scavenging activity and lung protection activity of the plant.

\section{Anticancer activity}

Cancer has become a major threat to the health of human beings. Scientific explorations are going on to discover anti-cancer drugs and medicine combinations to cure cancer [180]. The plant-based natural drugs have also received huge recognition in this exploration and more than one thousand species reported significant anticancer activities. From 1955 onwards, National Cancer Institute (NCI), USA supported the clinical screening of natural compounds for checking anti-cancer properties. Based on that, 114,000 plant-derived compounds were reported and twenty of them got approval for marketing [181]. Chemical compounds such as isoflavones, flavones, flavonoids, coumarins, anthocyanins, catechins, lignans and iso catechinsimpart free radical scavenging activity to plants that is important to tackle cancer [182]. Tetradecanoic acid (myristic acid), 9,12-octadecadienoic acid (Z, Z)- (linoleic acid), 9-octadecenoic acid (Z) (oleic acid), phytol, squalene and acetate are the main compounds from $S$. androgynus which mainly shows cancer-preventive properties [136]. Studies conducted by Rahmat et al. [22] revealed that ethanolic shoot extract of $S$. androgynus shows the inhibiting effects on the proliferation of the cancer cell lines of the breast. The bio-fabricated zinc oxide- $S$. androgynus nanoparticles displayed cytotoxic activity on MDAMB468 human triple-negative breast cancer (TNBC) and NIH3T3 mouse fibroblast cells. Apoptosis of TNBC cells was also observed which indicates the possibility of incorporation of modern technologies to the traditional plants [183]. Therefore it is clear that extension of research on Sauropus plants can contribute to cost-effective discovery of anticancer drugs using sustainable approaches.

\section{Antidiabetic activity}

In developing countries, herbal medicines have a key role to play in the dealing with the disease diabetes mellitus [184]. Indian people use $S$. androgynus plant leaves as antidiabetic and for improving vision [6]. The leaves of $S$. androgynus plants have the greater capability to decrease the blood glucose levels of humans which suggest their antidiabetic activity [102]. Indian people use this plant as a leafy vegetable [52]. The scientific evidence of hypoglycemic activity of $S$. androgynus leaves was provided by Suparmi et al. [25]. The streptozotocin-induced diabetes mellitus in male Wistar rats was treated with chlorophyll extracted from S.androgynus and it showed a significant hypoglycemic effect. Investigations by Kumar and George [185] also revealed the anti-diabetic activity of $S$. androgynus leaves in alloxan-induced diabetic mice. They found that $250 \mathrm{mg} / \mathrm{kg}$ and $500 \mathrm{mg} / \mathrm{kg}$ dosage of methanol extract of the leaves leads to the reduction of blood fasting sugar, lipid peroxidation rate and increased antioxidative enzymes such as superoxide dismutase. Since the potential of $S$. androgynous plants is evidenced from the pharmacological studies, they can be used as a natural remedy against this serious metabolic disorder, especially in a scenario, where the number of diabetes patients is predicted to be 439 million adults by 2030 .

\section{Antimicrobial activity}

Plants are rich sources of phytochemicals that can be structurally processed and optimised into drugs [186]. Medicinal plants rich in phytochemicals such as alkaloids, terpenes, polyphenols and glycosides show antimicrobial activities [186]. Ethanolic and methanolic extracts of the $S$. androgynus plant show predominant antibacterial activity against Staphylococcus aureus, Proteus vulgaris and Bacillus cereus [187]. According to Paul and Antos [188], the ethanolic leaf extract of this plant shows potential antibacterial properties against $S$. aureus and Klebsiella pneumonia. Methanol leaf extract of katuk shows a higher inhibitory effect against gram-positive bacteria, which is followed by ethanol and aqueous extract [49]. Leaf extract of the plant shows antibacterial activity against Staphylococcus aureus, Bacillus subtilis, Escherichia coli and Pseudomonas aeruginosa [189]. The infection of $E$. coli at the time of pregnancy causes hormonal imbalance, hepatic and renal necrosis. The pharmacological study by Christina et al. [190] proved that the combination of S. androgynus and Elephantopus scaber extract is capable of protecting pregnant mice from $E$. coli induced renal and hepatic necrosis. They have 
also revealed 75:25 proportion of the two plant extracts are capable of restoring progesterone to normal after the bacteria infection. Husna et al. [191] performed antimicrobial activity of various concentrations (20-100\%) of $S$. androgynus against $E$. coli and recorded significant activity. Besides humans, there are several issues faced by the other organisms also. Vibrio bacteria is the pathogen that causes vibriosis disease which is creating problems for the shrimp farmers that affect the survival of the shrimp larva. Nurfadillah et al. [43] showed that the 1200 ppm dosage of ethanoic extract of $S$. androgynus treatment generated the highest survival rate (93\%) of shrimp larvae infected with vibrio.

There is increasing evidence in favour of the evolution of antimicrobial resistance (AMR) bacterial strains and it is a major challenge at present. Excessive use of antibiotics is one of the reasons behind the widespread issue of AMR. Considering the evolution of new AMR strains, there is growing demand for naturally available sources of compounds that can target AMR bacteria. Interestingly, the extract $S$. androgynus shows antibacterial activity against antibiotic-resistant bacteria such as Staphylococcus aureus AMR strain. Rahayu et al. [192] demonstrated the antibacterial activity of the $60 \%$ ethanol extract of $S$. androgynus against methicillin-resistant, ampicillin-resistant Staphylococcus aureus strain. Bioactive components such as phenolics and flavonoids cause ultrastructural changes in the bacterial membrane which result in their growth reduction. The wounds induced by diabetes are susceptible to $S$. aureus infection, but this organism is resistant to antibiotic methicillin too. Prakoso et al. [193] studied the wound healing capacity of $S$. androgynus alcohol extract in mice with streptozotocininduced diabetes wounds. The wound was infected with methicillin-resistant $S$. aureus and they recorded a reduction in the infection rate with the extract. The extract was capable of increasing collagen deposition, the tensile strength of skin, skin thickness, vascular endothelial growth factor and decreasing expression of cyclooxygenase- 2 expression and C-reactive protein in the mice. If the foods we eat contain natural compounds against the AMR bacteria, it could possibly slow down the issue of AMR.

\section{Anti-inflammatory}

Medicinal plants displayed curation potential against health conditions such as inflammation [194]. Inflammation is the human body's normal response against pathogen attacks. During inflammation, accumulation of leukocytes occurs and termination of the response is triggered by pro-inflammatory signalling pathways. Failure of this termination mechanism can result in disease or chronic inflammation [195]. The modern drugs used for the treatment of inflammation pose a high risk of cardiovascular diseases and other side effects. The phytochemicals from plants are reported to modulate the pro-inflammatory signal transduction and thereby act as an effective anti-inflammatory agent without side effects [196]. Recently, Kim et al. [197] proved the curating efficiency of S. brevipes ethanol extract in gastritis. The oral administration of $S$. brevipes extract $(200 \mathrm{mg} / \mathrm{kg})$ reduced the inflammatory lesions in lipopolysaccharide-induced gastritis mice. Zhen et al. [198] proved the anti-inflammatory activity of another species viz. S. rostratus which is commonly found in China. Very little information is available on the anti-inflammatory activity of $S$. androgynus and further research should be conducted to prove and validate its anti-inflammatory activity [195].

\section{Antiobesity activity}

The excess accumulation of fat in the body can result in an unhealthy metabolic condition called obesity which further leads to the development of cardiovascular disorders, hypertension, stroke, diabetes mellitus, gallbladder diseases, cancer, and non-alcoholic fatty liver [199]. Therefore prevention of obesity, maintenance of stable and proper body mass index can help in preventing obesity associated diseases [200]. The latest treatment for obesity includes a change in lifestyle with a healthy diet and pharmacological treatments [199]. It was proved that compounds from medicinal plants can be used for inducing weight loss and preventing obesity [23]. $S$. androgynus is commonly used as a slimming agent especially in Taiwan and Malaysia. Its leaf extract is used in order to reduce body weight. S. androgynous salads, fries and beverages are taken by many people in the form of antiobesity extracts [55]. The chemical compound that is responsible for the anti-obesity properties in Sauropus plants is $3-\mathrm{O}-\beta$ - $\mathrm{D}$-glucosyl-(1-6)- $\beta$ - $\mathrm{D}$-glucosylkaempferol (GGK) [164]. S. androgynus leaf extract in combination with Zingiber ottensii rhizome showed a significant rate of adipose tissue protection [201]. Warditiani et al. [202] reported the antidyslipidemic activity (a condition to avoid the occurrence of one or more unhealthy lipids and lipoproteins in the blood). This study found that the saponin extract of S. androgynus is capable of reducing the concentrations of triglyceride, total cholesterol, high-density lipoprotein and low-density lipoprotein effectively in the fat-rich diet fed Wistar rats. Therefore it is understood that the inclusion of Sauropus leaves in the diet can help to fight against obesity and improve the health of the consumers.

\section{Lactation inducing activity}

Active compounds present in plants have a major role in the postnatal recovery of mothers since the plants have 
beneficial effects on mother and baby. Study by Ewueke and Chukwu proved that some plants increase lactation in the mother [203]. S. androgynus is very popular and it has been extensively used by people in Malaysia especially women for increasing breast milk production [6]. The combination of Plectranthus amboinicus and $S$. androgynus can also be used to increase breast milk production [97]. Leaf extracts of this plant aid in lactation [122]. The scientific evidence of lactation-inducing properties of $S$. androgynus is proved not only in humans but also in cattle. Noach et al. [204] proved that cattle feed supplemented with $S$. androgynus leaf powder increases milk production as well as body weight in pregnant cattle and calf respectively. Harjanti et al. [205] observed the positive effect of S. androgynus, Curcuma xanthorrhiza, and Alpinia galanga (70\%, 25\% and 5\% respectively) on milk production and milk quality in mastitis diseased cattle. Their study helped to reveal the therapeutic potential of S. androgynus against mastitis. Djati et al. [206] reported prolactin and erythrocyte inducing properties of $S$. androgynus leaves in pregnant mice induced with typhoid using Salmonella typhi. These studies prove the galactagogue property of $S$. androgynus.

\section{Antifungal activity}

As discussed, medicinal plants are potential sources of antimicrobial agents [207]. Several medicinal plants are used to treat a variety of fungal infections [208]. S. androgynus is traditionally used by Mekong Delta and Central highlands villagers of Vietnam against fungal infection [104]. Its phytochemicals such as flavonoids, tannins, carotenoids and anthocyanins are responsible for its antifungal properties [209]. Neophytadiene found in $S$. androgynus also shows antifungal properties [135].

\section{Anti-alopecia}

Alopecia leads to loss of hair [210]. S. androgynus plants can be used for the treatment of alopecia. Topical application of $S$. androgynus mixed with milk induces hair growth in bald people of Kampung Mak Kemas community, Malaysia [211]. Mustarichie et al. [167] demonstrated that $10-25 \%$ of ethanol extract-water fraction of $S$. androgynus is capable of inducing hair growth in male rabbits. Anti-alopecia property of S. androgynus was performed by Praceka et al. [212] and identified eleven compounds in their study namely, 6-piperidin-1Ylpyrimidine-2,4-diamine 3-oxide minoxidil, 5-alpha dihydrotestosterone, finasteride, 1,14-tetradecanediol, octadec-1-ene, 1-hexadecene, decanoic acid, phytol, azulene, pyrene and (4s,4's)-4,4'-(propane-1,3- diyl) bis(3-amino-4-ethyl 1h-pyrazole-5(4h)-one) through computation based molecular modelling.

\section{Anti-anaemia}

Anaemia is a major iron deficiency disorder that particularly affects women and children [213]. Consumption of iron and vitamin rich food can improve anaemia to a certain extent. The use of iron supplement tablets may result in health conditions such as neurogenic disorders, hemochromatosis, and even cancer [214]. Therefore utilisation of natural resources may be attempted to overcome anaemia. Exposure to air pollution can cause reduction in red blood cells and haemoglobin. Siswanto [215] proved that the ethanolic extract of $S$. androgynus is effective against anaemia and increase in RBC and haemoglobin was observed in the mice exposed to motorcycle smoke when treated with ethanolic extract ( $200 \mathrm{mg} / \mathrm{kg}$ weight). Indrayani et al. [39] found that combined extract of $S$. androgynous and $M$. oleiefera raises the haemoglobin and ferritin in rats. Suparmi et al. [25] also obtained similar results with chlorophyll extract of $S$. androgynus. This study observed an increase in haemoglobin and ferritin quantity in sodium nitrate induced anaemic mice.

\section{Antimalarial activity}

Malaria is a major disease that affects tropical countries, especially developing countries. Antimalarial activity of S. androgynus was explored by Mahardiani et al. [216] and reported significant cytotoxicity against Plasmodium falciparum in the Huh7 liver cell lines. Zou et al. [44] revealed the antimalarial activity of another species viz. S. spatulifolius (90\% of methanol extract) against the pathogen Plasmodium falciparum.

\section{Antitussive effect}

Antitussive medicines have wide popularity all over the world due to the prevalence of cough [26]. Natural bioactive compounds contribute significantly to the relief of cough and cold [217]. Several studies have explored the antitussive activity of herbal medicines [26, 218-220]. S. spatulifolius reported remarkable antitussive activity against ammonia-liquor induced cough in mice with $75 \%$ ethanol and ethyl acetate extract. The study was focused on the effect of the extracts on ATP-sensitive potassium channels and opioid receptors and it showed positive activity [24].

\section{Analgesic activity}

The actual or potential tissue damage can result in pain [221]. The most popular narcotic drugs used for relief from pain are associated with several side effects [222]. 
So, there exists a demand to develop analgesic drugs from traditional medicinal and other phytochemical resources [221]. The analgesic activity of the S. rostratus was analysed with acetic acid-induced pain and hot plate induced heat simulation on mice. It was found that the aqueous extract of the plant has the capacity to reduce pain twists in mice [198]. Selvi et al. [47] also reported the analgesic activity of $S$. androgynus leaf extract in the rats where a hot plate test was applied to induce pain and dese dependent inhibition of hot plate reaction was observed.

\section{Antiulcer activity}

The anti-ulcer characteristics of $S$. androgynus was revealed by Roosdiana et al. [45]. The ethanolic extract of S. androgynus was used for the treatment of peptic ulcers in rats in an aspirin-induced model. It was found that $48.6 \mathrm{mg} / 200 \mathrm{~g} \mathrm{BW}$ was the most efficient dose in the rats and it induced the tissue repair protein tumour necrosis factor-alpha (TNF- $\alpha$ ) at the time of inflammation (Table 6).

\section{Toxicity of Sauropus androgynus}

Several studies showed that regular consumption of $S$. androgynus leads to obstructive ventilatory impairment especially in patients with respiratory symptoms $[6,228]$. Overconsumption of papaverine is known to cause bronchiolitis obliterans [6]. Since S. androgynus contains papaverine, further studies were conducted to investigate its role in bronchiolitis obliterans disease [20]. In Taiwan and Japan, young and middleaged women who consumed $S$. androgynus extracts for weight control, later developed bronchiolitis obliterans $[229,230]$. Similar findings were also obtained by Ger et al. [231] suggesting potential side effects of $S$. androgynus. Yu et al. [98] observed the cytotoxic effect of S. androgynus in mouse embryonic fibroblast NIH3T3 cells. The ethyl acetate (EtOAc) extract of the plants recorded the highest inhibition of cell growth and the results reveal apoptosis and necrosis effects of the $S$. androgynus extract [98]. Papaverine at a dose of $200 \mathrm{mg} /$ day is used as antispasmodic, but if it is taken in larger amounts can result in constipation, drowsiness and increased reflex excitability [232]. Hsiue et al. [233] found that people in Taiwan who consumed S. androgynus in higher amounts developed minor to severe obstructive ventilatory problems within 6-7 months and it was very common in people who ingested more than 3600 g. Ou et al. [234] reported that there is no long-term effect of the $S$. androgynus on lung diseases. Chronic ingestion of katuk extract more than $131 \mathrm{~g} /$ day is associated with insomnia, weight loss, breathing difficulty, poor appetite, palpitation, cough, skin rashes and dizziness [235]. Omar et al. [225] observed the teratogenic activity of $S$. androgynus $(10-1000 \mu \mathrm{g} / \mathrm{mL})$ in the zebrafish. Therefore it is very important to consider the toxicological properties of the plant while preferring for consumption and disease treatments.

\section{Conclusions}

Sauropus androgynus is an important green leafy vegetable with high nutritional and therapeutic potential. This comprehensive review discusses the multiple ethnic dishes obtained from it and its use in ethnomedicinal preparations. Extensive review of literature shows that it is a multipurpose plant with uses in various ethnic food and ethnomedicinal preparations. It has a very high regional importance among the people in South, East and Southeast Asia. Documentation of regionally available ethnic food systems and investigation of their dietary contributions is crucial in the present context considering the recurrent lockdowns and disruptions of the supply chains in long distance food transportation. The presence of various phytochemicals such as phenols, terpenoids, tannins, steroids, alkaloids, fatty acids, flavonoids, and volatile oils makes it a very important medicinal and edible herb. These compounds might be responsible for its bioactivities as revealed by pharmacological studies. It has been pharmacologically demonstrated that $S$. androgynus have significant antioxidant, anti-cancerous, antidiabetic, antimicrobial, and anti-inflammatory, anti obesity, and lactation inducing, antifungal, anti-alopecia, anti-anaemia, antitussive, analgesic and antiulcer activities. But further extensive in vivo and clinical studies are required to validate its medicinal activities. Several toxicological effects such as bronchiolitis obliterans, insomnia, weight loss, dizziness and teratogenic activity of $S$. androgynus provide an idea about its potential side effects. The future studies should be focused on the investigation of more bioactive compounds and their potential roles in treating diseases. Isolation of some of the pure compounds and developing drugs from them is also an important area of research. Scientific research on its cultivation, development of varieties that are nutritionally superior should also be attempted. The recent research shows the importance of the regionally relevant local traditional/ethnic food systems. Therefore, this comprehensive review on the ethnic foods that are prepared from $S$. androgynus is very timely and more such studies should be attempted to document the plant based ethnic food systems from various parts of the world. The contributions of the regional ethnic food systems to the food security and food system resilience in times of situations such as pandemics should be empirically demonstrated 


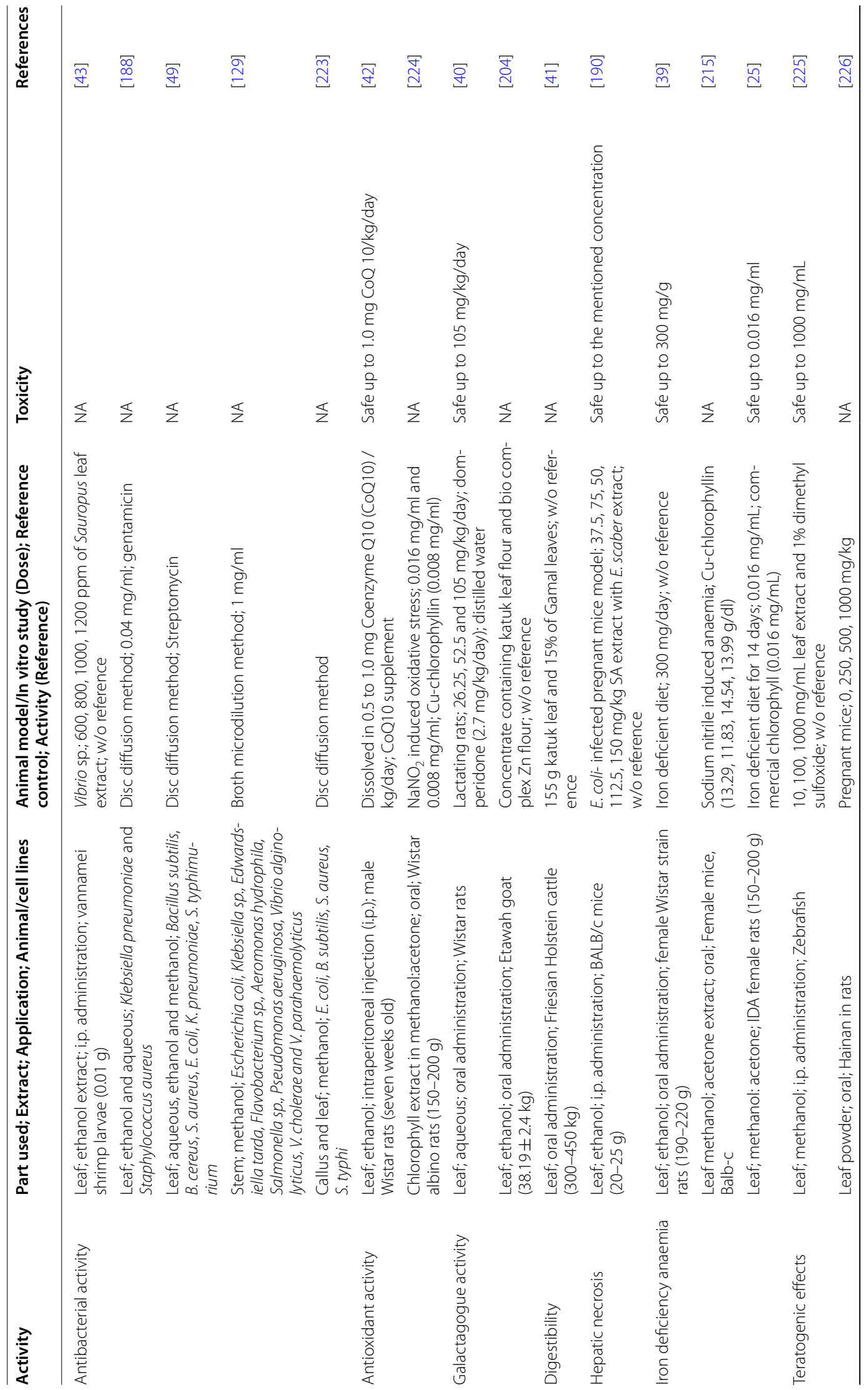




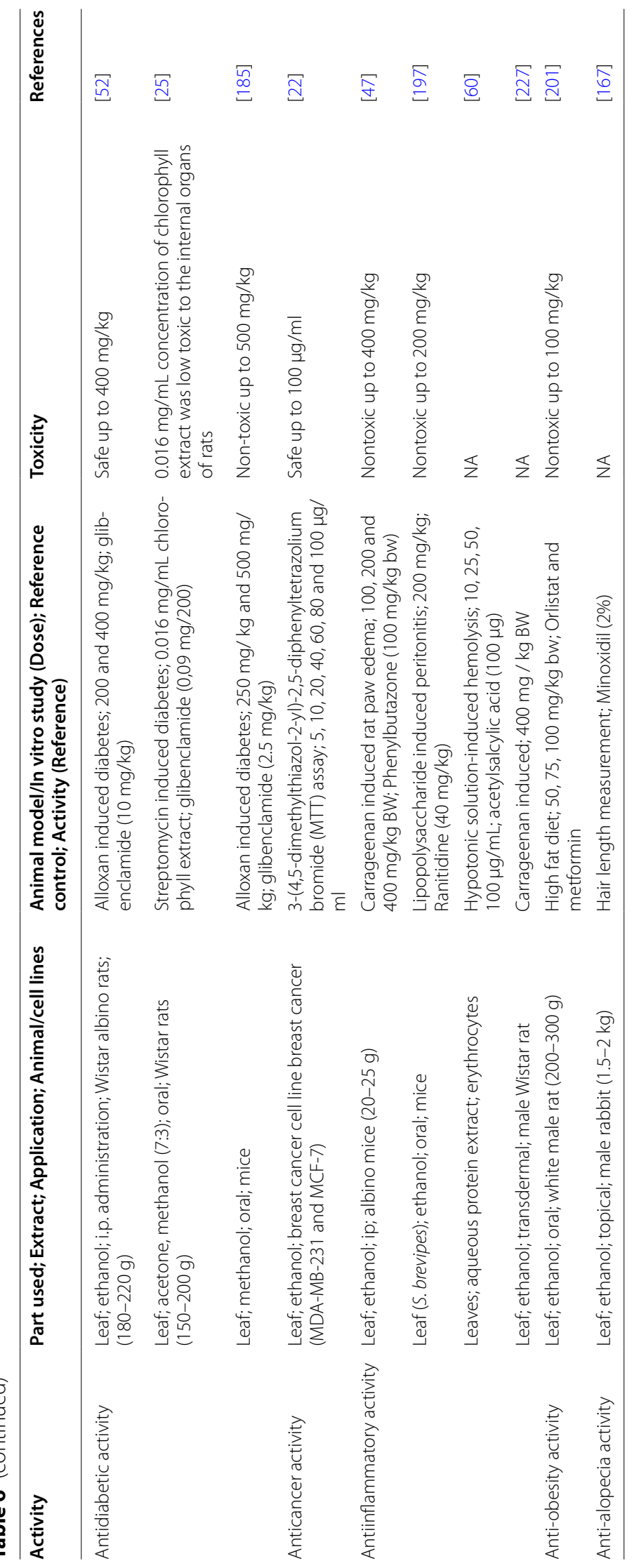




\section{to devise future strategies aimed at strengthening the local food systems.}

\begin{abstract}
Abbreviations
BO: Bronchiolitis obliterans; DPPH: 2,2-Diphenyl-1-picryl-hydrazyl-hydrate; EtOAc: Ethyl acetate; FRAP: Ferric reducing antioxidant power assay; FTIR: Fourier Transform Infrared spectroscopy; GC-MS: Gas Chromatography-Mass Spectroscopy; GGK: 3-O-B-D-glucosyl-(1-6)-- $\beta$-D-glucosyl-kaempferol; RBC: Red blood cells; SA: Sauropus androgynus; TNBC: Triple negative breast cancer.
\end{abstract}

\section{Acknowledgements}

Authors are thankful to the Central University of Kerala, Kerala, India for providing logistic support to carry out the study. TA gratefully acknowledges CSIR for providing her fellowship in the form of JRF.

\section{Authors' contributions}

All authors equally contributed. All authors read and approved the final manuscript.

\section{Funding}

No specific funding received.

\section{Availability of data and materials}

All material/data used are available in the manuscript.

\section{Declarations}

Ethics approval and consent to participate

Not applicable.

\section{Consent for publication}

All authors consent to publish this paper if accepted.

\section{Competing interests}

The authors have no competing or conflict of interest to disclose.

Received: 29 November 2021 Accepted: 19 February 2022

Published online: 07 March 2022

\section{References}

1. Prakash V, et al. Introduction: the importance of traditional and ethnic food in the context of food safety, harmonization, and regulations. In: Prakash V, Martín-Belloso O, Keener L, Astley S, Braun S, McMahon H, et al., editors. Regulating safety of traditional ethnic foods. San Diego: Academic Press; 2016. p. 1-6. https://doi.org/10.1016/B978-0-12800605-4.00001-3.

2. Khoury CK, Bjorkman AD, Dempewolf H, Ramirez-Villegas J, Guarino $L$, Jarvis A, et al. Increasing homogeneity in global food supplies and the implications for food security. Proc Natl Acad Sci. 2014;111:4001-6. https://doi.org/10.1073/pnas.1313490111.

3. Ojeda-Linares C, Álvarez-Ríos GD, Figueredo-Urbina C, Islas LA, LappeOliveras P, Nabhan GP, et al. Traditional fermented beverages of Mexico: A biocultural unseen foodscape. Foods. 2021;10:2390. https://doi.org/ 10.3390/foods 10102390

4. Raseroka K. Information transformation Africa: Indigenous knowledgeSecuring space in the knowledge society. Int Inf Libr Rev. 2008;40:24350. https://doi.org/10.1080/10572317.2008.10762789.

5. Mollee E, Pouliot M, McDonald MA. Into the urban wild: Collection of wild urban plants for food and medicine in Kampala. Uganda Land Use Policy. 2017;63:67-77. https://doi.org/10.1016/.landusepol.2017.01.020.

6. Bunawan H, Bunawan SN, Baharum SN, Noor NM. Sauropus androgynus (L.) Merr. Induced bronchiolitis obliterans: from botanical studies to toxicology. Evid-Based Complement Altern Med. 2015;2015:714158. https://doi.org/10.1155/2015/714158.
7. Welzen PC. Revision of the Malesian and Thai species of Sauropus (Euphorbiaceae: Phyllanthoideae). Blumea. 2003;48:319-91. https://doi. org/10.3767/000651903X675017.

8. Li PT, Chiu H, Ma J. Euphobaceae. In: Wu ZY, Rave PH, Hong DY, editors. Flora China, vol. 11. Beijing: Science Press; 2008. p. 163-314.

9. Hobbs JE. Food supply chains during the COVID-19 pandemic. Can J Agric Econ Can Agroeconomie. 2020;68:171-6. https://doi.org/10. $1111 / \mathrm{cjag} .12237$.

10. van der Ploeg JD. From biomedical to politico-economic crisis: the food system in times of Covid-19. J Peasant Stud. 2020;47:944-72. https://doi.org/10.1080/03066150.2020.1794843.

11. Silva SJS, Pena L. Collapse of the public health system and the emergence of new variants during the second wave of the COVID-19 pandemic in Brazil. One Health. 2021;13: 100287. https://doi.org/10. 1016/j.onehlt.2021.100287.

12. Kuhnlein HV. Food system sustainability for health and well-being of Indigenous peoples. Public Health Nutr. 2015;18:2415-24. https://doi. org/10.1017/S1368980014002961.

13. Lal R. Home gardening and urban agriculture for advancing food and nutritional security in response to the COVID-19 pandemic. Food Secur. 2020;12:871-6. https://doi.org/10.1007/s12571-020-01058-3.

14. Mullins L, Charlebois S, Finch E, Music J. Home food gardening in Canada in response to the COVID-19 pandemic. Sustainability. 2021;13:3056. https://doi.org/10.3390/su13063056.

15. Odhav B, Beekrum S, Akula U, Baijnath H. Preliminary assessment of nutritional value of traditional leafy vegetables in KwaZulu-Natal. South Africa J Food Compos Anal. 2007;20:430-5. https://doi.org/10. 1016/j.jfca.2006.04.015.

16. Rensburg WSJ, Venter SL, Netshiluvhi TR, van den Heever E, Vorster $\mathrm{HJ}$, de Ronde JA, et al. Role of indigenous leafy vegetables in combating hunger and malnutrition. South Afr J Bot. 2004;70:52-9. https:// doi.org/10.1016/S0254-6299(15)30268-4.

17. Chanda S. Importance of pharmacognostic study of medicinal plants: An overview. J Pharmacogn Phytochem. 2014;2:69-73.

18. Sheldon JW, Balick MJ, Laird SA. Medicinal Plants: Can Utilization and Conservation Coexist?: 12. Bronx, N.Y., U.S.A: New York Botanical Garden Pr Dept; 1997.

19. Moyo SM, Serem JC, Bester MJ, Mavumengwana V, Kayitesi E. African green leafy vegetables health benefits beyond nutrition. Food Rev Int. 2021;37:601-18. https://doi.org/10.1080/87559129.2020.1717519.

20. Zhang B-D, Cheng J-X, Zhang C-F, Bai Y-D, Liu W-Y, Li W, et al. Sauropus androgynus L. Merr-A phytochemical, pharmacological and toxicological review. J Ethnopharmacol. 2020;257:112778. https://doi. org/10.1016/j.jep.2020.112778.

21. Yunita O, Rantam F, Yuwono M. Metabolic fingerprinting of Sauropus androgynus (L.) Merr. leaf extracts. Pharm Sci Asia. 2019;46:69-79. https://doi.org/10.29090/psa.2019.02.017.0043.

22. Rahmat A, Kumar V, Fong LM, Endrini S, Sani HA. Determination of total antioxidant activity in three types of local vegetables shoots and the cytotoxic effect of their ethanolic extracts against different cancer cell lines. Asia Pac J Clin Nutr. 2004:13:308-11.

23. Hasani-Ranjbar S, Jouyandeh Z, Abdollahi M. A systematic review of anti-obesity medicinal plants - an update. J Diabetes Metab Disord. 2013;12:28. https://doi.org/10.1186/2251-6581-12-28.

24. Qiu Q. Antitussive effect and mechanism study of effective fractions from Sauropus rostratus. Chin Tradit Herb Drugs. 2019;50:1430-4. https://doi.org/10.7501/j.issn.0253-2670.2019.06.026.

25. Suparmi S, Fasitasari M, Martosupono M, Mangimbulude J. Hypoglycemic and antianemia effects of chlorophyll from Sauropus androgynus (L) Merr leaves in rats. Pharmacogn J. 2021. https://doi.org/10. 5530/pj.2021.13.119.

26. Saha S, Nosál'ová G, Ghosh D, Flešková D, Capek P, Ray B. Structural features and in vivo antitussive activity of the water extracted polymer from Glycyrrhiza glabra. Int J Biol Macromol. 2011:48:634-8. https://doi.org/10.1016/j.ijbiomac.2011.02.003.

27. French BR. Food crops of Solomon Islands-A brief introduction to the crops, vol. 41. Burnie: Food Plants International Inc; 2011.

28. Suksri S, Premcharoen S, Thawatphan C, Sangthongprow S. Ethnobotany in Bung Khong Long non-hunting area. Northeast Thailand Kasetsart J Nat Sci. 2005;39:519-33. 
29. Bingtao L, Gilbert MG. Sauropus, Euphorbiaceae. Flora China. 2008;11:202.

30. Price M, Berkelaar D. ECHO Development Notes. Echo communications; 2008.

31. Kehlenbeck K. Rural Homegardens in Central Sulawesi, Indonesia: An example for a sustainable agro-ecosystem. University of Göttingen, 2007.

32. Padmavathi P, Rao MP. Nutritive value of Sauropus androgynus leaves. Plant Foods Hum Nutr Dordr Neth. 1990;40:107-13. https://doi.org/ 10.1007/BF02193767.

33. Petrus A. Sauropus androgynus (L.) Merrill-A potentially nutritive functional leafy vegetable. Asian J Chem. 2013;25:9425-33. https:// doi.org/10.14233/ajchem.2013.15405.

34. Sheela K, Nath KG, Vijayalakshmi D, Yankanchi GM, Patil RB. Proximate composition of underutilized green leafy vegetables in southern Karnataka. J Hum Ecol. 2004;15:227-9. https://doi.org/10.1080/09709 274.2004.11905698.

35. Chatterjee S, Mukherjee D, Mani A, Choudhuri P. Nutritional status of chekurmanis (Sauropus androgynous L.), 2019, p. 207-18.

36. Ronald K, Lodhi M, Kanwal K, Arya S, Roona, Sunmoni. Wild edible plants used by the ethnic communities of Shi Yomi District of Arunachal Pradesh, India. Pleione 2019;13:247-57. https://doi.org/10. 26679/Pleione.13.2.2019.247-257.

37. Maghirang RG, Oraye CD, Antonio MO, Cacal MS. Ethnobotanical studies of some plants commonly used as vegetables in selected provinces of the Philippines. J Nat Stud. 2018;8:30-43.

38. Ogle BM, Xuan Dung NN, Thanh Do T, Hambraeus L. The contribution of wild vegetables to micronutrient intakes among women: an example from the Mekong delta, Vietnam: Ecology of food and nutrition. Ecol Food Nutr. 2001;40:159-84. https://doi.org/10.1080/03670244. 2001.9991646.

39. Indrayani UD, Sarosa H, Hussaana A, Widiyanto B. The effects comparisons of Sauropus androgynous, Moringa oleiefera alone and in combination on iron deficiency in anemia rats. Bangladesh J Med Sci. 2019;18:136-40. https://doi.org/10.3329/bjms.v18i1.39564.

40. Mustofa, Yuliani FS, Purwono S, Sadewa AH, Damayanti E, Heriyanto DS. Polyherbal formula (ASILACT ${ }^{\circledR}$ ) induces milk production in lactating rats through upregulation of a-Lactalbumin and aquaporin expression. BMC Complement Med Ther 2020;20:368. https://doi.org/ 10.1186/s12906-020-03152-7.

41. Sutomo S, Garantjang S, Natsir A, Ako A. Consumption and in vivo digestibility of feed supplemented by katuk (Sauropus androgynus) and gamal (Gliricidia sepium) leaves in friesian holstein cattle. IOP Conf Ser Earth Environ Sci. 2020;473:1-6. https://doi.org/10.1088/ 1755-1315/473/1/012119.

42. Kettawan A, Wunjuntuk K. Quantitation, Absorption and tissue distribution of coenzyme q10 from pak-wanban (Sauropus androgynus L. Merr.) leaf and its antioxidant activities. Walailak J Sci Technol WJST. 2021;18:6774. https://doi.org/10.48048/wjst.2021.6774.

43. Nurfadillah N, Zahara R, Rahimi SAE, Arisa II, Perdana AW, Dewi CD, et al. The effectiveness of katuk leaves extract (Sauropus androgynous) as an antibacterial Vibrio sp. on the survival rate and growth of vannamei shrimp larvae (Litopenaeus vannamei). IOP Ser Earth Environ Sci. 2021;74:1-4. https://doi.org/10.1088/1755-1315/674/1/ 012069.

44. Zou Y-S, Foubert K, Tuenter E, Lemière F, Cos P, Maes L, et al. Antiplasmodial and cytotoxic activities of Striga asiatica and Sauropus spatulifolius extracts, and their isolated constituents. Phytochem Lett. 2013;1:53-8. https://doi.org/10.1016/j.phytol.2012.10.018.

45. Roosdiana A, Yudandi SA, Erika A. The potency of ethanolic extract of Sauropus androgynus (L.) Merr leaves as therapeutic herbal of rats (Rattus norvegicus) peptic ulcer model induced by aspirin. IOP Conf Ser Mater Sci Eng. 2018;299:012018. https://doi.org/10.1088/1757899X/299/1/012018.

46. Unuofin JO, Lebelo SL. Antioxidant effects and mechanisms of medicinal plants and their bioactive compounds for the prevention and treatment of type 2 diabetes: an updated review. Oxid Med Cell Longev. 2020;2020:1356893. https://doi.org/10.1155/2020/1356893.

47. Selvi A, Bhaskar S. Anti-inflammatory and analgesic activities of the Sauropus androgynus (L) Merr. (Euphorbiaceae) Plant in experimental animal models. Pharm Lett. 2012;4:782-5.
48. Raveendran D, Samu J, Thomas A. Preliminary phytochemical studies of hydroalcoholic extract of $S$. androgynus leaves. World J Pharm Res. 2018;7:1680-6.

49. Ariharan VN, Devi V, Prasad PN. Antibacterial activity of Sauropus androgynus leaf extracts against some pathogenic bacteria. Int J Chem Environ Pharm Res. 2013;6:134-7.

50. Xia B, Shen S, Xue F. Phytoextraction of heavy metals from highly contaminated soils using Sauropus androgynus. Soil Sediment Contam Int J. 2013;22:631-40. https://doi.org/10.1080/15320383.2013.756452.

51. Shaw HKA. The Euphorbiaceae of Central Malesia (Celebes, Moluccas, Lesser Sunda Is.). Kew: Springer on behalf of Royal Botanic Gardens; 1982.

52. Sujila V, Biju CR, Babu G. Evaluation of antidiabetic activity of bioactive constituent of Sauropus androgynus in alloxan induced diabetic Rats and effect on inhibition of a-glucosidase enzyme. J Pharmacognacy Phytochem. 2016:5:80-4.

53. Muralidharan R, Narasimhan D. In vitro anticancer activity of Majidea zanquebarica J. Krik. ex Oliv. (Sapindaceae) J Appl Pharm Sci 2012;2:1235. https://doi.org/10.7324/JAPS.2012.21024.

54. Sarkar A, Dey M, Mazumder M. Ecological status of medicinal plants of Chalsa forest range under Jalpaiguri division, West Bengal, India. Undefined 2017.

55. ArifT, Shetty GR. Therapeutic potential and traditional uses of Sauropus androgynous: a review. J Pharmacogn Phytochem. 2020;9:2131-7.

56. Kumar SS, Badhmapriya D, Kalaimathi S. Determination of bioactive compounds in S. androgynus (L.) Merr. through IR irradiation. Int J Adv Res Rev. 2020;5:27-34.

57. Lyons G, Goebel R, Stanley K-J, Tikai P, Kafa R, Taufa L, et al. Feasibility study on increasing the consumption of nutritionally rich leafy vegetables by Indigenous communities in Samoa, Solomon Islands and northern Australia. Australia: ACIAR GPO Box 1571 Canberra ACT 2601; 2017.

58. Mipun P, Bhat NA, Borah D, Kumar Y. Non-timber forest products and their contribution to healthcare and livelihood security among the Karbi tribe in Northeast India. Ecol Process. 2019;8:41. https://doi.org/ 10.1186/s13717-019-0194-4.

59. Chinese pharmocopia commisiion. Pharmacopoeia of the People's Republic of China, vol. 1. Beijing: China Medical Science Press; 2015.

60. Madhu CS, Manukumar HMG, Basavaraju P. New-vista in finding antioxidant and anti-inflammatory property of crude protein extract from Sauropus androgynus leaf. Acta Sci Pol Technol Aliment. 2014;13:375-83. https://doi.org/10.17306/J.AFS.2014.4.4.

61. Naveena E, Janavi G, Arumugam T, Anitha T. Estimation of nutritive composition of Sauropus androgynus (Multivitamin plant) at different growth stages and position of leaves. Int J Chem Stud. 2020;8:443-7. https://doi.org/10.22271/chemi.2020.v8.i3e.9251.

62. Platel K, Srinivasan K. Nutritional profile of chekurmanis (Sauropus androgynus), A less explored green leafy vegetable. Indian J Nutr Diet. 2017;54:243-52. https://doi.org/10.21048/ijnd.2017.54.3.15765.

63. Yusuf S, Suprapti S, Istanto I, rina mulyaningsih T, Sutisna S, Alfian A. Determination of micro essential element Fe in foodstuffs using instrumental neutron activation analysis (INAA). J Phys Conf Ser. 2020;1436:012072. https://doi.org/10.1088/1742-6596/1436/1/012072.

64. Santoso U, Kususiyah Y, Fenita. Effect of Sauropus androgynus leaves extract (sale) on fat deposition in broiler fed low protein diets. J Indones Trop Anim Agric 2013;38:176-84. https://doi.org/10.14710/jitaa.38.3. 176-184.

65. Awaludin A, Kartina K, Maulianawati D, Manalu W, Andriyanto A Septiana R, et al. Short Communication: Phytochemical screening and toxicity of ethanol extract of Sauropus androgynus. Biodiversitas J Biol Divers. 2020. https://doi.org/10.13057/biodiv/d2175925.

66. Maisuthisakul P, Pasuk S, Ritthiruangdej P. Relationship between antioxidant properties and chemical composition of some Thai plants. J Food Compos Anal. 2008;21:229-40. https://doi.org/10.1016/j.jfca.2007.11. 005.

67. Ly J, Agus PIP, Keban A, Henuk YL. Effect of sweet leaves (Sauropus androgynus $L$ Merr) meal inclusion into basal feed on performance and IOFC of growing pigs. IOP Conf Ser Earth Environ Sci. 2020;454: 012065. https://doi.org/10.1088/1755-1315/454/1/012065.

68. Andarwulan N, Kurniasih D, Apriady RA, Rahmat H, Roto AV, Bolling BW. Polyphenols, carotenoids, and ascorbic acid in underutilized medicinal 
vegetables. J Funct Foods. 2012;4:339-47. https://doi.org/10.1016/j.jf. 2012.01.003.

69. Ahnen RT, Jonnalagadda SS, Slavin JL. Role of plant protein in nutrition, wellness, and health. Nutr Rev. 2019;77:735-47. https://doi.org/10.1093/ nutrit/nuz028.

70. Sree L, Vijayalakshmi K. Proximate composition, nutritional evaluation and mineral analysis in the leaves of an indigenous medicinal plant Alternanthera sessilis. Int J Health Sci. 2018;8:55-62.

71. Nguyen N, Tien H, Tran TT, Tan Quoc LP. Chlorophyll content and antioxidant activity from folium sauropi (Sauropus androgynus (L.) Merr) with microwave-assisted extraction. IOP Conf Ser Mater Sci Eng. 2020;991:012036. https://doi.org/10.1088/1757-899X/991/1/012036.

72. Hong J-E, Lim J-H, Kim T-Y, Jang H-Y, Oh H-B, Chung B-G, et al. Photooxidative protection of chlorophyll a in C-Phycocyanin aqueous medium. Antioxidants. 2020;9:1235. https://doi.org/10.3390/antiox9121 235.

73. Glick NR, Fischer MH. The role of essential fatty acids in human health. J Evid Based Integr Med. 2013;18:268-89. https://doi.org/10.1177/21565 87213488788.

74. Maryati Y, Susilowati A, Aspiyanto MH, Artanti N, Budiari S. Evaluation of antioxidant activity of formulated functional drinks derived from katuk (Sauropus androgynous) leaf extracts: optimization using response surface methodology (RSM). AIP Conf Proc. 2019;2175:020018. https:// doi.org/10.1063/1.5134582.

75. Abbaspour N, Hurrell R, Kelishadi R. Review on iron and its importance for human health. J Res Med Sci Off J Isfahan Univ Med Sci. 2014;19:164-74.

76. Singh S, Singh DR, Salim KM, Srivastava A, Singh LB, Srivastava RC. Estimation of proximate composition, micronutrients and phytochemical compounds in traditional vegetables from Andaman and Nicobar Islands. Int J Food Sci Nutr. 2011;62:765-73. https://doi.org/10.3109/ 09637486.2011 .585961$.

77. Cabot C, Martos S, Llugany M, Gallego B, Tolrà R, Poschenrieder C. A role for zinc in plant defense against pathogens and herbivores. Front Plant Sci. 2019;10:1171-1171. https://doi.org/10.3389/fpls.2019.01171.

78. Alejandro S, Höller S, Meier B, Peiter E. Manganese in Plants: From acquisition to subcellular allocation. Front Plant Sci. 2020;11:300. https://doi. org/10.3389/fpls.2020.00300.

79. Printz B, Lutts S, Hausman J-F, Sergeant K. Copper trafficking in plants and its implication on cell wall dynamics. Front Plant Sci. 2016;7:601. https://doi.org/10.3389/fpls.2016.00601.

80. Soetan $\mathrm{K}$, Olaiya C, Oyewole O. The importance of mineral elements for humans, domestic animals and plants: A review. Afr J Food Sci 2009;4.

81. Yamada K. Cobalt: its role in health and disease. Met lons Life Sci. 2013;13:295-320. https://doi.org/10.1007/978-94-007-7500-8_9.

82. Dawson MI. The importance of vitamin A in nutrition. Curr Pharm Des. 2000;6:311-25. https://doi.org/10.2174/1381612003401190.

83. Rizvi S, Raza ST, Ahmed F, Ahmad A, Abbas S, Mahdi F. The role of Vitamin $\mathrm{E}$ in human health and some diseases. Sultan Qaboos Univ Med J. 2014;14:e157-65.

84. Johnson EJ. The role of carotenoids in human health. Nutr Clin Care Off Publ Tufts Univ. 2002;5:56-65. https://doi.org/10.1046/j.1523-5408.2002. 00004.x.

85. Fabbri ADT, Crosby GA. A review of the impact of preparation and cooking on the nutritional quality of vegetables and legumes. Int J Gastron Food Sci. 2016;3:2-11. https://doi.org/10.1016/j.ijgfs.2015.11.001.

86. Tian J, Chen J, Ye X, Chen S. Health benefits of the potato affected by domestic cooking: a review. Food Chem. 2016;202:165-75. https://doi. org/10.1016/j.foodchem.2016.01.120.

87. Arumsari I, MÄkynen K, Adisakwattana S, Ngamukote S. Effects of different cooking methods and palm oil addition on the bioaccessibility of beta-carotene of sweet leaf (Sauropus androgynous). J Nutr Sci Vitaminol (Tokyo) 2020;66:S202-5. https://doi.org/10.3177/jnsv.66.S202.

88. Azima F, Azben A, Refdi CW, Aulia HS, Syukri D. Effect of different cooking methods on the content of vitamin C, phenolics and minerals in several green leafy vegetables. Pak J Nutr. 2020;19:160-5. https://doi. org/10.3923/pjn.2020.160.165.

89. Martorell R, de Romaña DL. Components of successful staple food fortification programs: lessons from Latin America. Food Nutr Bull. 2017;38:384-404. https://doi.org/10.1177/0379572117707890.
90. Hasrini R, Aviana T, Khoiriyah A. Fortification of modified cassava flour (Mocaf) cookies with rich nutrition vegetable powder. E3S Web Conf 2021;232:03009. https://doi.org/10.1051/e3sconf/202123203009.

91. Dewita, Desmelati, Edison, Syahrul. The development of instant (dried) sago noodles fortified with functional components. IOP Conf Ser Earth Environ Sci 2019;253:012018. https://doi.org/10.1088/1755-1315/253/1/ 012018.

92. Lamxay V, de Boer HJ, Björk L. Traditions and plant use during pregnancy, childbirth and postpartum recovery by the Kry ethnic group in Lao PDR. J Ethnobiol Ethnomedicine. 2011;7:14. https://doi.org/10. 1186/1746-4269-7-14.

93. Phumthum M, Srithi K, Inta A, Junsongduang A, Tangjitman K, Pongamornkul W, et al. Ethnomedicinal plant diversity in Thailand. J Ethnopharmacol. 2018;214:90-8. https://doi.org/10.1016/j.jep.2017.12.003.

94. Rao PK, Hasan SS, Bhellum BL, Manhas RK. Ethnomedicinal plants of Kathua district, J\&K. India J Ethnopharmacol. 2015;171:12-27. https:// doi.org/10.1016/j.jep.2015.05.028.

95. Bunalema L, Obakiro S, Tabuti JRS, Waako P. Knowledge on plants used traditionally in the treatment of tuberculosis in Uganda. J Ethnopharmacol. 2014;151:999-1004. https://doi.org/10.1016/j.jep.2013.12.020.

96. Lee JY, Lin QC, Pan WD. Woody and wild plants of Sauropus androgynus. J Agric Sci 1998

97. Silalahi M, Khairiah A. Ethnomedicinal plants and practices related to pregnancy, childbirth, and postpartum healthcare of Minangkabau ethnic group, West Sumatra. Indonesia Biodiversitas J Biol Divers. 2020. https://doi.org/10.13057/biodiv/d211018.

98. Yu S-F, Chen T-M, Chen Y-H. Apoptosis and necrosis are involved in the toxicity of Sauropus androgynus in an in vitro study. J Formos Med Assoc Taiwan Yi Zhi. 2007;106:537-47. https://doi.org/10.1016/S09296646(07)60004-7.

99. Syawal S, Garantiang S, Natsir A, Ako A. The effect of katuk (Sauropus androgynus) and gamal (Gliricidia sepium) supplementation on the dry matter digestibility, organic matter digestibility, and milk quality of Friesian Holstein. IOP Conf Ser Earth Environ Sci. 2020;492: 012017. https:// doi.org/10.1088/1755-1315/492/1/012017.

100. Hayati A, Arumingtyas EL, Indriyani S, Hakim L. Local knowledge of katuk (Sauropus androgynus (L.) Merr) in east Java. Indonesia. 2016;7:210-5.

101. Sujarwo W, Keim AP, Savo V, Guarrera PM, Caneva G. Ethnobotanical study of Loloh: Traditional herbal drinks from Bali (Indonesia). J Ethnopharmacol. 2015;169:34-48. https://doi.org/10.1016/j.jep.2015.03.079.

102. Sai KS, Srividya N. Blood glucose lowering effect of the leaves of Tinospora cordifolia and Sauropus androgynus in diabetic subjects. J Nat Remedies. 2002;2:28-32. https://doi.org/10.18311/jnr/2002/341.

103. Neamsuvan O, Ruangrit T. A survey of herbal weeds that are used to treat gastrointestinal disorders from southern Thailand: Krabi and Songkhla provinces. J Ethnopharmacol. 2017;196:84-93. https://doi.org/10. 1016/j.jep.2016.11.033.

104. Ogle BM, Tuyet HT, Duyet HN, Xuan Dung NN. Food, feed or medicine: the multiple functions of edible wild plants in Vietnam. Econ Bot. 2003;57:103-17. https://doi.org/10.1663/0013-0001(2003)057[0103 FFOMTM]2.0.CO;2.

105. Moromi T. Ethnomedicinal plants used by the sonowal kacharis of Bhekulajan village in Dibrugarh District, Assam, NE India. Int J Environ Sci. 2014;3:54-7.

106. Prabhu N, Padigar S, Aithal R. Few Herbal Medicinal knowledge from Thirthahalli taluk, Shivamogga District, Karnataka. India J Ayurveda Med Sci. 2017;2:240-3. https://doi.org/10.5530/jams.2017.2.24.

107. Joseph JM, Thomas B, Rajendran A, Prabhu KKM. Medicinal chasmophytes of Urumbikkara hills, Idukki district, Kerala, India. J Pharm Sci Tech. 2015;5:11-7.

108. Anjalam A, Kalpana S, Vijai D, Premalatha S. Documentation of medicinal plants used by malayali tribes in Kolli Hills. Int J Adv Res. 2016:3:101-7.

109. Baruah S, Borthakur S, Gogoi P, Ahmed M. Ethnomedicinal plants used by Adi-Minyong tribe of Arunachal Pradesh, eastern Himalaya. IJNPR. 2013:4:278-82.

110. Shukla A, Montanari B, Nurpen MT, Bawitlung SL. Decoction: a valuable ethnobotanical treatment for the tribal communities of the Seven Sister States of North East India. AJMP. 2018;6:404-11. https://doi.org/10. 15413/ajmp.2018.0178. 
111. Kris-Etherton PM, Hecker KD, Bonanome A, Coval SM, Binkoski AE, Hilpert KF, et al. Bioactive compounds in foods: their role in the prevention of cardiovascular disease and cancer. Am J Med. 2002;113(Suppl 9B):71S-88S. https://doi.org/10.1016/s0002-9343(01)00995-0.

112. Borges CV, Minatel IO, Gomez-Gomez HA, Lima GPP. Medicinal Plants: Influence of Environmental Factors on the Content of Secondary Metabolites. In: Ghorbanpour M, Varma A, editors. Med. Plants Environ. Chall., Cham: Springer International Publishing; 2017, p. 259-77. https:// doi.org/10.1007/978-3-319-68717-9_15.

113. Jain C, Khatana S, Vijayvergia R. Bioactivity of secondary metabolites of various plants: a review. Int J Pharm Sci Res. 2019;10:494. https://doi. org/10.13040/IJPSR.0975-8232.10(2).494-04.

114. Hunter D, Borelli T, Beltrame DMO, Oliveira CNS, Coradin L, Wasike VW, et al. The potential of neglected and underutilized species for improving diets and nutrition. Planta. 2019;250:709-29. https://doi.org/10. 1007/s00425-019-03169-4.

115. Tiwari SC, Husain N. Biological activities and role of flavonoids in human health. Indian J Sci Res. 2017;12:193-6.

116. Cushnie TPT, Lamb AJ. Antimicrobial activity of flavonoids. Int J Antimicrob Agents. 2005;26:343-56. https://doi.org/10.1016/j.jjantimicag. 2005.09.002.

117. Zandi K, Teoh B, Sam S, Wong P, Mustafa MR, AbuBakar S. Antiviral activity of four types of bioflavonoid against dengue virus type-2. Virol J. 2011;8:560. https://doi.org/10.1186/1743-422X-8-560.

118. Lamson DW, Brignall MS. Antioxidants and cancer, part 3: quercetin. Altern Med Rev J Clin Ther. 2000;5:196-208.

119. Satija A, Hu FB. Plant-based diets and cardiovascular health. Trends Cardiovasc Med. 2018;28:437-41. https://doi.org/10.1016/j.tcm.2018.02. 004.

120. Christen S, Woodall AA, Shigenaga MK, Southwell-Keely PT, Duncan MW, Ames BN. gamma-tocopherol traps mutagenic electrophiles such as $\mathrm{NO}(\mathrm{X})$ and complements alpha-tocopherol: physiological implications. Proc Natl Acad Sci USA. 1997;94:3217-22. https://doi.org/10.1073/ pnas.94.7.3217.

121. Inada M, Shindo M, Kobayashi K, Sato A, Yamamoto Y, Akasaki Y, et al. Anticancer effects of a non-narcotic opium alkaloid medicine, papaverine, in human glioblastoma cells. PLoS ONE. 2019;14:e0216358. https:// doi.org/10.1371/journal.pone.0216358.

122. Soka S, Alam H, Boenjamin N, Agustina TW, Suhartono MT. Effect of Sauropus androgynus leaf extracts on the expression of prolactin and oxytocin genes in lactating BALB/C mice. J Nutr Nutr. 2010;3:31-6. https://doi.org/10.1159/000319710.

123. Zhang J, Zhu W-F, Zhu W-Y, Yang PP, Xu J, Manosroi J, et al. Melanogenesis-Inhibitory and cytotoxic activities of chemical constituents from the leaves of Sauropus androgynus L. Merr. (Euphorbiaceae). Chem Biodivers. 2018;15:1. https://doi.org/10.1002/cbdv.201700486.

124. D'Agostino G, Diano S. Alpha-melanocyte stimulating hormone: production and degradation. J Mol Med Berl Ger. 2010;88:1195-201. https://doi.org/10.1007/s00109-010-0651-0.

125. Huong PTT, Tai BH, Nhiem NX, Cuong NX, Quang TH, Thu VK, et al. Saurobacciosides A-C: three new glycosides from Sauropus bacciformis with their cytotoxic activity. Nat Prod Res. 2021. https://doi.org/10 1080/14786419.2021.1892670.

126. Sawasdee N, Chaveerach A, Tanee T, Suwannakud KS, Ponkham P, Sudmoon R. Sauropus species containing eudesmin and their DNA profile. Asian J Agric Biol. 2019;7:412-22

127. Liu H, Song Z, Liao D-G, Zhang T-Y, Liu F, Zhuang K, et al. Anticonvulsant and sedative effects of eudesmin isolated from Acorus tatarinowii on mice and rats. Phytother Res. 2015;29:996-1003. https://doi.org/10. 1002/ptr.5337.

128. Jiang L-L, Sun B-R, Zheng C, Yang G-L. The antitumour effects of eudesmin on lung cancer by inducing apoptosis via mitochondriamediated pathway in the tumour cells. Pharm Biol. 2017;55:2259-63. https://doi.org/10.1080/13880209.2017.1401647.

129. Wei LS, Wee W, Siong JYF, Syamsumir DF. Characterization of antimicrobial, antioxidant, anticancer properties and chemical composition of Sauropus androgynus stem extract. Acta Medica Litu. 2011;18:12-6. https://doi.org/10.6001/actamedica.v18i1.1808.

130. Rajanandh MG, Kavitha J. Quantitative estimation of $\beta$-sitosterol, total phenolic and flavonoid compounds in the leaves of Moringa oleifera. Int J PharmTech Res. 2010;2:1409-14.
131. Zhen AO, Piao MJ, Kang KA, Madushan Fernando PD, Kang HK, Koh YS, et al. Niacinamide protects skin cells from oxidative stress induced by particulate matter. Biomol Ther. 2019;27:562-9. https://doi.org/10.4062/ biomolther.2019.061.

132. Chen AY, Chen YC. A review of the dietary flavonoid, kaempferol on human health and cancer chemoprevention. Food Chem. 2013;138:2099-107. https://doi.org/10.1016/j.foodchem.2012.11.139.

133. Wang C, Li W, Liu H, Wang J, Li G, Wang G, et al. Five natural carbohydrates from the leaves of Sauropus rostratus. Carbohydr Res. 2014;384:99-101. https://doi.org/10.1016/j.carres.2013.12.004.

134. Fikri F, Purnama MTE. Pharmacology and phytochemistry overview on Sauropus androgynous. Syst Rev Pharm. 2020;11:2020. https://doi.org/ 10.31838/srp.2020.6.20.

135. Kuttinath S, Kh H, Rammohan R. Phytochemical screening, antioxidant, antimicrobial, and antibiofilm activity of Sauropus androgynus leaf extracts. Asian J Pharm Clin Res. 2019. https://doi.org/10.22159/ajpcr. 2019.v12i4.31756.

136. Bose R, Kumar M, Manivel A, Mohan C. Chemical Constituents of Sauropus androgynus and evaluation of its antioxidant activity. Res J Phytochem. 2018;12:7-13. https://doi.org/10.3923/rjphyto.2018.7.13.

137. Tholl D. Biosynthesis and biological functions of terpenoids in plants. Adv Biochem Eng Biotechnol. 2015;148:63-106. https://doi.org/10. 1007/10_2014_295.

138. Chung KT, Wong TY, Wei Cl, Huang YW, Lin Y. Tannins and human health: a review. Crit Rev Food Sci Nutr. 1998;38:421-64. https://doi.org/ 10.1080/10408699891274273.

139. Laveena KB, Chandra M. Evaluation of bioactive compounds, antioxidant, and antibacterial properties of medicinal plants Sauropus androgynus $L$ and Erythrina variegata L. Asian J Pharm Clin Res. 2018;11:313. https://doi.org/10.22159/ajpcr.2018.v11i12.28207.

140. Shi J, Arunasalam K, Yeung D, Kakuda Y, Mittal G, Jiang Y. Saponins from edible legumes: chemistry, processing, and health benefits. J Med Food. 2004;7:67-78. https://doi.org/10.1089/109662004322984734.

141. Martínez-Valverde I, Periago MJ, Ros G. Nutritional importance of phenolic compounds in the diet. Arch Latinoam Nutr. 2000;50:5-18.

142. Kong J, Chia L, Goh N, Chia T, Brouillard R. Analysis and biological activities of anthocyanins. Phytochemistry. 2003;64:923-33. https://doi.org/ 10.1016/S0031-9422(03)00438-2.

143. Santoso U, Fenita Y. The effect of Sauropus androgynus leaf extract on performance, egg quality and chemical composition of eggs. J Indones Trop Anim Agric. 2016. https://doi.org/10.14710/jitaa.41.3.125-134.

144. McGaw LJ, Jäger AK, van Staden J. Antibacterial effects of fatty acids and related compounds from plants. South Afr J Bot. 2002;68:417-23. https://doi.org/10.1016/S0254-6299(15)30367-7.

145. Carta G, Murru E, Banni S, Manca C. Palmitic Acid: Physiological role, metabolism and nutritional implications. Front Physiol. 2017:8:902. https://doi.org/10.3389/fphys.2017.00902.

146. Chen X, Zhao X, Deng Y, Bu X, Ye H, Guo N. Antimicrobial potential of myristic acid against Listeria monocytogenes in milk. J Antibiot (Tokyo). 2019;72:1. https://doi.org/10.1038/s41429-019-0152-5.

147. Harada H, Yamashita U, Kurihara H, Fukushi E, Kawabata J, Kamei Y. Antitumor activity of palmitic acid found as a selective cytotoxic substance in a marine red alga. Anticancer Res. 2002;22:2587-90.

148. Prasath KG, Alexpandi R, Parasuraman R, Pavithra M, Ravi AV, Pandian SK. Anti-inflammatory potential of myristic acid and palmitic acid synergism against systemic candidiasis in Danio rerio (Zebrafish). Biomed Pharmacother Biomedecine Pharmacother. 2021;133: 111043. https:// doi.org/10.1016/j.biopha.2020.111043.

149. Takato T, Iwata K, Murakami C, Wada Y, Sakane F. Chronic administration of myristic acid improves hyperglycaemia in the Nagoya-ShibataYasuda mouse model of congenital type 2 diabetes. Diabetologia. 2017;60:2076-83. https://doi.org/10.1007/s00125-017-4366-4.

150. da Silva LLD, Nascimento M, Siqueira Silva DH, Furlan M, da Silva BV. Antibacterial activity of a stearic acid derivative from Stemodia foliosa. Planta Med. 2002;68:1137-9. https://doi.org/10.1055/s-2002-36346.

151. Jubie S, Ramesh PN, Dhanabal P, Kalirajan R, Muruganantham N, Shanish AA. Synthesis, antidepressant and antimicrobial activities of some novel stearic acid analogues. Eur J Med Chem. 2012;54:931-5. https:// doi.org/10.1016/j.ejmech.2012.06.025. 
152. Pan P, Lin S, Ou Y, Chen W, Chuang Y, Yen Y, et al. Stearic acid attenuates cholestasis-induced liver injury. Biochem Biophys Res Commun. 2010;391:1537-42. https://doi.org/10.1016/j.bbrc.2009.12.119.

153. Alabi KA, Lajide L, Owolabi BJ. Biological activities of oleic acid and its primary amide: experimental and computational studies. J Chem Soc Niger. 2018;43:38-49.

154. Carrillo Pérez C, Cavia Camarero MM, de la Torre SA. Antitumor effect of oleic acid; mechanisms of action. A review. Efecto antitumoral del ácido oleico; mecanismos de acción: revisión científica 2012;27:1860-1865. https://doi.org/10.3305/nh.2012.27.6.6010

155. Wei C, Yen P, Chang S, Cheng P, Lo Y, Liao VH. Antioxidative activities of both oleic acid and Camellia tenuifolia seed oil are regulated by the transcription factor DAF-16/FOXO in Caenorhabditis elegans. PLOS ONE. 2016;11:e0157195. https://doi.org/10.1371/journal.pone.0157195.

156. Rock C, Jacob A, Bowen PE. Update on the biological characteristics of the antioxidant micronutrients: Vitamin C, Vitamin E, and the carotenoids. J Am Diet Assoc. 1996;96:693-702. https://doi.org/10.1016/ S0002-8223(96)00190-3.

157. Abdullah KM, Arefeen A, Shamsi A, Alhumaydhi FA, Naseem I. Insight into the In vitro antiglycation and In vivo antidiabetic effects of Thiamine: implications of Vitamin B1 in controlling diabetes. ACS Omega. 2021;6:12605-14. https://doi.org/10.1021/acsomega.1c00631.

158. Ozsvari B, Bonuccelli G, Sanchez-Alvarez R, Foster R, Sotgia F, Lisanti MP. Targeting flavin-containing enzymes eliminates cancer stem cells (CSCs), by inhibiting mitochondrial respiration: Vitamin B2 (Riboflavin) in cancer therapy. Aging. 2017;9:2610-28. https://doi.org/10.18632/ aging. 101351.

159. Sanches SC, Ramalho LNZ, Mendes-Braz M, Terra VA, Cecchini R, Augusto MJ, et al. Riboflavin (vitamin B-2) reduces hepatocellular injury following liver ischaemia and reperfusion in mice. Food Chem Toxicol. 2014:67:65-71. https://doi.org/10.1016/j.fct.2014.02.013.

160. Araki S, Mamoru S, Masatoshi F, Makoto K. Enhancement of resistance to bacterial infection in mice by vitamin B2. J Vet Med Sci. 1995;57:599602. https://doi.org/10.1292/jvms.57.599.

161. Velu G, Palanichamy V, Rajan AP. Phytochemical and Pharmacological Importance of Plant Secondary Metabolites in Modern Medicine. In: Roopan SM, Madhumitha G, editors. Bioorganic Phase Nat. Food Overv., Cham: Springer International Publishing; 2018, p. 135-56. https://doi. org/10.1007/978-3-319-74210-6_8.

162. Atuah KN, Hughes D, Pirmohamed M. Clinical pharmacology. Drug Saf 2004;27:535-54. https://doi.org/10.2165/00002018-200427080-00006.

163. Bhaskar A, Ramesh KV, Rajeshwari. Wound healing profile of Sauropus androgynus in Wistar Rats. J Nat Remedies 2009;9:159-64. https://doi. org/10.18311/jnr/2009/235.

164. Yu S-F, Shun C-T, Chen T-M, Chen Y-H. 3-O- $\beta$-D-glucosyl- $(1 \rightarrow 6)-\beta-D-$ glucosyl-kaempferol isolated from Sauropus androgynus reduces body weight gain in Wistar rats. Biol Pharm Bull. 2006;29:2510-3. https://doi. org/10.1248/bpb.29.2510

165. Sutharson L. Xanthine oxidase inhibitory activity of some leafy vegetables collected from Palakkad regions of Kerala. Int J Pharm Sci Res. 2016;7:1-5.

166. Susilowati R, Khoiriyah L, Hikmah E, Hikmah E. Estrogenic effect of the leaves from katuk (Sauropus androgynus L. Merr) on vaginal and endometrial atrophy in perimenopausal mice. Pharmacogn J. 2020;12:240-5. https://doi.org/10.5530/pj.2020.12.37.

167. Mustarichie R, Wicaksono IA, Hayati C. Anti-alopecia characteristics of ethanol extract, n-hexane, ethyl acetate and water fractions of Malvaviscus arboreus Cav. Res J Pharm Technol. 2018;11:5066-72. https://doi. org/10.5958/0974-360X.2018.00924.1.

168. Abuajah $\mathrm{Cl}$, Ogbonna AC, Osuji CM. Functional components and medicinal properties of food: a review. J Food Sci Technol. 2015:52:2522-9. https://doi.org/10.1007/s13197-014-1396-5.

169. Choe $E$, Min DB. Chemistry and reactions of reactive oxygen species in foods. Crit Rev Food Sci Nutr. 2006;46:1-22. https://doi.org/10.1080/ 10408390500455474.

170. Marnett LJ. Oxyradicals and DNA damage. Carcinogenesis. 2000;21:361-70. https://doi.org/10.1093/carcin/21.3.361.

171. Kasote DM, Katyare SS, Hegde MV, Bae H. Significance of antioxidant potential of plants and its relevance to therapeutic applications. Int J Biol Sci. 2015;11:982-91. https://doi.org/10.7150/ijbs.12096.
172. Halliwell B. Reactive species and antioxidants. Redox biology is a fundamental theme of aerobic life. Plant Physiol. 2006;141:312-22. https:// doi.org/10.1104/pp.106.077073.

173. Zehiroglu C, Ozturk Sarikaya SB. The importance of antioxidants and place in today's scientific and technological studies. J Food Sci Technol. 2019;56:4757-74. https://doi.org/10.1007/s13197-019-03952-x.

174. Wilson DW, Nash P, Buttar HS, Griffiths K, Singh R, De Meester F, et al. The role of food antioxidants, benefits of functional foods, and influence of feeding habits on the health of the older person: An overview. Antioxid Basel Switz. 2017;6:E81. https://doi.org/10.3390/antiox6040 081.

175. Sharma US, Kumar A. In vitro antioxidant activity of Rubus ellipticus fruits. J Adv Pharm Technol Res. 2011;2:47-50. https://doi.org/10.4103/ 2231-4040.79805.

176. Ermi Hikmawanti NP, Fatmawati S, Asri AW. The effect of ethanol concentrations as the extraction solvent on antioxidant activity of katuk (Sauropus androgynus (L.) Merr.) leaves extracts. IOP Conf Ser Earth Environ Sci. 2021;755:120. https://doi.org/10.1088/1755-1315/755/1/ 012060.

177. Nasution Z, Chuen T. Improvement of fiber content, total phenolic content, and antioxidant activity in fresh egg pasta with incorporation of cekur manis (Sauropus androgynus L.Merrill). 2011.

178. Badami S, Channabasavaraj KP. In Vitro. Antioxidant activity of thirteen medicinal plants of India's Western ghats. Pharm Biol. 2007;45:392-6. https://doi.org/10.1080/13880200701215141.

179. Petchang R. Enhancement of the enzymatic and non-enzymatic antioxidant activities of cultured Sauropus androgynus L. merr. shoots treated with UV-C irradiation. Walailak J Sci Technol. 2018;16:867-73. https://doi.org/10.48048/wjst.2019.4391

180. Mukherjee AK, Basu S, Sarkar N, Ghosh AC. Advances in cancer therapy with plant based natural products. Curr Med Chem. 2001;8:1467-86. https://doi.org/10.2174/0929867013372094.

181. Cragg GM, Newman DJ. Discovery and development of antineoplastic agents from natural sources. Cancer Invest. 1999;17:153-63.

182. Raina H, Soni G, Jauhari N, Sharma N, Bharadvaja N. Phytochemical importance of medicinal plants as potential sources of anticancer agents. Turk J Bot. 2014;38:1027-35.

183. D’Souza JN, Nagaraja GK, Prabhu A, Navada KM, Kouser S, Manasa DJ. Sauropus androgynus (L.) leaf phytochemical activated biocompatible zinc oxide nanoparticles: an antineoplastic agent against human triple negative breast cancer and a potent nanocatalyst for dye degradation. Appl Surf Sci. 2021;552:149429. https://doi.org/10.1016/j.apsusc.2021. 149429.

184. Bnouham M, Ziyyat A, Mekhfi H, Tahri A, Legssyer A. Medicinal plants with potential antidiabetic activity - a review of ten years of herbal medicine research (1990-2000). Int J Diabetes Metab. 2006;14:1-25. https://doi.org/10.1159/000497588.

185. Kumar PR, George P. Antidiabetic effect of Sauropus androgynus L. leaves in alloxan induced diabetic mice. J Pure Appl Microbiol. 2015;9:2565-71.

186. Ugboko HU, Nwinyi OC, Oranusi SU, Fatoki TH, Omonhinmin CA. Antimicrobial importance of medicinal plants in Nigeria. Sci World J. 2020;2020: e7059323. https://doi.org/10.1155/2020/7059323.

187. Gayathramma K, Pavani KV, Raji R. Chemical constituents and antimicrobial activities of certain plant parts of Sauropus androgynus L. Int J Pharma Bio Sci. 2012;3:561-6.

188. Paul M, Anto KB. Antibacterial activity of Sauropus androgynus (L.) Merr. Int J Plant Sci. 2010;6:189-92.

189. Palaksha MN, Aishwarya KS, Arpitha SM, Kumar P, Kumar R, Koushik M. Evaluation of in-vitro antibacterial and anthelmintic activities of Sauropus androgynus (Phyllanthaceae) plant extracts. Int J Pharmacogn Chin Med. 2019:3:1-7. https://doi.org/10.23880/ipcm-16000160.

190. Christina YI, Diana MR, Fuzianingsih EN, Nurhayati null, Ridwan FN, Widodo null, et al. Hormone-balancing and protective effect of combined extract of Sauropus androgynus and Elephantopus scaber against Escherichia coli-induced renal and hepatic necrosis in pregnant mice. J Ayurveda Integr Med 2021;12:245-53. https://doi.org/10.1016/j.jaim. 2020.09.001.

191. Husna CA, Al-Muqsith A-M, Soya Loviana H. The difference in the antimicrobial effect of katuk leaf extract (Sauropus androgynus (I) Merr) 
Concentration against Escherichia coli. Proc MICoMS 2017 Emerald Reach Proc Ser Vol 1 2018;1:361366.

192. Rahayu A, Rini CS, Prakoso YA, Palgunadi BU, Munandar MA. Effects of Sauropus androgynus extract and its combination with ampicillin against Methicillin-resistant Staphylococcus aureus: an in vitro study. Int J One Health. 2020;6:128-33. https://doi.org/10.14202/IJOH.2020 128-133.

193. Prakoso YA, Kurniasih K, Wijayanti A, Kristianingrum Y. Treatment of experimentally induced diabetic wound infected with methicillinresistant Staphylococcus aureus using Aloe vera, Apium graveolens, and Sauropus androgynus extracts in rats. Int J One Health. 2019;5:99-106. https://doi.org/10.14202/IJOH.2019.99-106.

194. Murugesan D, Deviponnuswamy R. Potential anti-inflammatory medicinal plants_a review. Int J Pharm Pharm Sci. 2014;6:43-9.

195. Recio CM, Andujar I, Rios JL. Anti-Inflammatory agents from plants: progress and potential. Curr Med Chem. 2012;19:2088-103. https://doi. org/10.2174/092986712800229069.

196. Balunas MJ, Kinghorn AD. Drug discovery from medicinal plants. Life Sci. 2005;78:431-41. https://doi.org/10.1016/j.lfs.2005.09.012.

197. Kim JH, Park JG, Hong YH, Shin KK, Kim JK, Kim Y-D, et al. Sauropus brevipes ethanol extract negatively regulates inflammatory responses in vivo and in vitro by targeting Src, Syk and IRAK1. Pharm Biol. 2021;59:74-86. https://doi.org/10.1080/13880209.2020.1866024.

198. Zhen HS, Liu R, Qiu Q, Jiang JG, Yang YY. Anti-inflammatory and analgesic effect of Sauropus rostratus. Chin J Exp Tradit Med Formulae. 2013;19:270-3.

199. Kim SH, Chun HJ, Choi HS, Kim ES, Keum B, Jeen YT. Current status of intragastric balloon for obesity treatment. World J Gastroenterol. 2016;22:5495-504. https://doi.org/10.3748/wjg.v22.i24.5495.

200. Pi-Sunyer X. The medical risks of obesity. Postgrad Med. 2009;121:21-33. https://doi.org/10.3810/pgm.2009.11.2074

201. Sulaeman A, Hasimun P, Gg N. Black bangle (Zingiber ottensii Val.) rhizome and katuk leaves (Sauropus androgynus L. Merr.) extract combination protective role on adipose tissues histologic profile of high-fat and carbohydrate diet-induced obese male rats. Asian J Pharm Clin Res. 2018;11:225. https://doi.org/10.22159/ajpcr.2018.v11s1.26613.

202. Warditiani NK, Milawati, Susanti NMP. Anti dyslipidemic activity of katuk leaves saponins fraction (Sauropus androgynus (L) merr) in rats induced with fat-rich diet. Int J Pharm Pharm Sci 2016:418-20.

203. Iwueke VA, Chukwu CE. Ethnotherapeutic profile of medicinal plants used during postnatal recovery (Postpartum) in South Eastern Nigeria: a review. Arch Curr Res Int. 2020;1:31-41. https://doi.org/10.9734/acri/ 2020/v20i530195

204. Noach YR, Handayani HT, Henuk YL. Birth weight, milk production, and milk quality of Ettawah grade goat at first kidding period sup plemented with concentrate contained katuk (Sauropus androgynous) leaf flour and Zn bio complex. IOP Conf Ser Earth Environ Sci. 2020:454:012060. https://doi.org/10.1088/1755-1315/454/1/012060.

205. Harjanti D, Wahyono F, Affah D. Milk production and milk quality of sub-clinical mastitis cows feed with different supplementation of herbal in the diet. IOP Conf Ser Earth Environ Sci. 2019;250:012062. https://doi.org/10.1088/1755-1315/250/1/012062.

206. Djati MS, Rahma YA, Dwijayanti DR, Rifai M, Rahayu S. Synergistic effect of Elephantopus scaber $L$ and Sauropus androgynus $L$ merr extracts in modulating prolactin hormone and erythropoiesis in pregnant typhoid mice. Trop J Pharm Res. 2017;16:1789-95. https://doi.org/10.4314/tjpr. v16i8.6.

207. Mahesh B, Satish S. Antimicrobial activity of some important medicinal plant against plant and human pathogens. J Agric Sci 2007;4.

208. Murtaza G, Mukhtar M, Sarfraz A. A review: antifungal potentials of medicinal plants. J Bioresour Manag. 2015. https://doi.org/10.35691/ JBM.5102.0018.

209. Chan YS, Cheah YH, Chong PZ, Khor HL, Teh WS, Khoo KS, et al. Antifungal and cytotoxic activities of selected medicinal plants from Malaysia. Pak J Pharm Sci. 2018:31:119-27.

210. Hunt $\mathrm{N}$, McHale $\mathrm{S}$. The psychological impact of alopecia. BMJ. 2005;331:951-3. https://doi.org/10.1136/bmj.331.7522.951.

211. Ong HC, Zuki RM, Milow P. Traditional knowledge of medicinal plants among the Malay villagers in Kampung Mak Kemas, Terengganu. Malaysia Stud Ethno-Med. 2011;5:175-85. https://doi.org/10.1080/ 09735070.2011.11886407.
212. Praceka MS, Megantara S, Mustarichie R. Journal of global pharma technology molecular modeling of anti-alopecia compounds found in Sauropus androgynus. J Glob Pharma Technol. 2020;12:939-47. https:// doi.org/10.13140/RG.2.2.25592.67848.

213. Saha U, Dharwadkar P, Sur S, Vishaharshini V, Malleshappa M. Plant extracts as an astounding remedy to anemia-a review. Ann Plant Sci. 2018;7:2166. https://doi.org/10.21746/aps.2018.7.4.16.

214. Padula M. Characterisation of the carotenoids and assessment of the vitamin a value of Brasilian guavas (Psidium guajava L.). Food Chem. 1986;20:11-9. https://doi.org/10.1016/0308-8146(86)90163-9.

215. Siswanto B. The effect of ethanol extract of katuk leaves (Sauropus androgynus) on red blood cell count (HR), Hemoglobin ( $\mathrm{Hb})$, and Hematocrit (Ht) of Rats Exposed to Emission. Pharmacogn J. 2021;13:860-5. https://doi.org/10.5530/pj.2021.13.110.

216. Mahardiani A, Suciati S, Ekasari W. In vitro antimalarial and cytotoxic activities of Sauropus androgynus leaves extracts. Trop J Nat Prod Res. 2020;4:558-62. https://doi.org/10.26538/tjnpr/v4i9.11.

217. Chattopadhyay N, Nosál'ová G, Saha S, Bandyopadhyay SS, Flešková D, Ray B. Structural features and antitussive activity of water extracted polysaccharide from Adhatoda vasica. Carbohydr Polym. 2011:83:19704. https://doi.org/10.1016/j.carbpol.2010.11.002.

218. Mukherjee PK, Saha K, Bhattacharya S, Giri SN, Pal M, Saha BP. Studies on antitussive activity of Drymaria cordata Willd. (Caryophyllaceae). J Ethnopharmacol. 1997;56:77-80. https://doi.org/10.1016/S0378-8741(97) 01512-2.

219. Bhakta T, Mukherjee PK, Saha K, Pal M, Saha BP. Studies on antitussive activity of Cassia fistula (Leguminosae) leaf extract. Pharm Biol. 1998;36:140-3. https://doi.org/10.1076/phbi.36.2.140.4598.

220. Dhawan K, Sharma A. Antitussive activity of the methanol extract of Passiflora incarnata leaves. Fitoterapia. 2002;73:397-9. https://doi.org/ 10.1016/s0367-326x(02)00116-8.

221. Safarabadi AM, Abbaszadeh S, Sepahvand H, Ebrahimi F. An overview of the important analgesic herbs in Iran. Anaesth Pain Intensive Care 2018;22.

222. Pilotto A, Franceschi M, Leandro G, Paris F, Niro V, Longo MG, et al. The risk of upper gastrointestinal bleeding in elderly users of aspirin and other non-steroidal anti-inflammatory drugs: the role of gastroprotective drugs. Aging Clin Exp Res. 2003;15:494-9. https://doi.org/10.1007/ BF03327372.

223. Govindaraju M, Chikkamadaiah M, Mahadevamurthy M, Mylari MH, Singh SM. Evaluation of phytochemicals and antibacterial activity of leaf and leaf derived callus extracts of Artemisia annua $\mathrm{L}$ and Sauropus androgynus (L) Merr. J Appl Nat Sci. 2016;8:2189-95. https://doi.org/10. 31018/jans.v8i4.1110.

224. Suparmi S, Fasitasari M, Martosupono M, Mangimbulude JC. Comparisons of curative effects of chlorophyll from Sauropus androgynus (L) Merr leaf extract and cu-chlorophyllin on sodium nitrate-induced oxidative stress in rats. J Toxicol. 2016;2016:e8515089. https://doi.org/ 10.1155/2016/8515089.

225. Omar A, Kue CS, Dianita R, Yu K. Teratogenic potential of traditional Malaysian vegetables (ulam) in the zebrafish model 2020. https://doi. org/10.1108/bf-02-2020-0118.

226. Zheng DX, Huang YY, Lin WH. Embryo toxicity and teratogenecity of Sauropus androgynus in rats. Mod Prev Med. 2011;11:327-32.

227. Desnita R, Luliana S, Anastasia DS. Antiinflammatory activity patch ethanol extract of leaf katuk (Sauropus androgynus L. Merr.). J IImu Kefarmasian Indones. 2018;16:1-5. https://doi.org/10.35814/jifi.v16i1. 493.

228. Wu CL, Hsu WH, Chiang CD, Kao CH, Hung DZ, King SL, et al. Lung injury related to consuming Sauropus androgynus vegetable. J Toxicol Clin Toxicol. 1997;35:241-8. https://doi.org/10.3109/15563659709001207.

229. Lai RS, Chiang AA, Wu MT, Wang JS, Lai NS, Lu JY, et al. Outbreak of bronchiolitis obliterans associated with consumption of Sauropus androgynus in Taiwan. Lancet Lond Engl. 1996;348:83-5. https://doi.org/ 10.1016/s0140-6736(96)00450-3.

230. Oonakahara K, Matsuyama W, Higashimoto I, Machida K, Kawabata $\mathrm{M}$, Arimura K, et al. Outbreak of Bronchiolitis obliterans associated with consumption of Sauropus androgynus in Japan-alert of foodassociated pulmonary disorders from Japan. Respir Int Rev Thorac Dis. 2005;72:221. https://doi.org/10.1159/000084058. 
231. Ger LP, Chiang AA, Lai RS, Chen SM, Tseng CJ. Association of Sauropus androgynus and bronchiolitis obliterans syndrome: a hospital-based case-control study. Am J Epidemiol. 1997;145:842-9. https://doi.org/10. 1093/oxfordjournals.aje.a009178.

232. Bender AE, Ismail KS. Nutritive value \& toxicity of a Malaysian food, Sauropus albicans. Plant Foods Man. 1975;1:139-43. https://doi.org/10 1080/03062686.1975.11904165.

233. Hsiue TR, Guo YL, Chen KW, Chen CW, Lee CH, Chang HY. Doseresponse relationship and irreversible obstructive ventilatory defect in patients with consumption of Sauropus androgynus. Chest. 1998;113:71-6. https://doi.org/10.1378/chest.113.1.71.

234. Ou C-Y, Chen C-Z, Lee C-H, Lin C-C, Chang H-Y, Hsiue T-R. Pulmonary function change in patients with Sauropus androgynus-related obstructive lung disease 15 years later. J Formos Med Assoc Taiwan Yi Zhi. 2013;112:630-4. https://doi.org/10.1016/j.jfma.2012.07.042.

235. Lin TJ, Lu CC, Chen KW, Deng JF. Outbreak of obstructive ventilatory impairment associated with consumption of Sauropus androgynus vegetable. J Toxicol Clin Toxicol. 1996;34:1-8. https://doi.org/10.3109/ 15563659609020224 .

\section{Publisher's Note}

Springer Nature remains neutral with regard to jurisdictional claims in published maps and institutional affiliations.

- fast, convenient online submission

- thorough peer review by experienced researchers in your field

- rapid publication on acceptance

- support for research data, including large and complex data types

- gold Open Access which fosters wider collaboration and increased citations

- maximum visibility for your research: over 100M website views per year

At BMC, research is always in progress.

Learn more biomedcentral.com/submissions 